\title{
THE DISAPPEARING DEFINED BENEFIT PENSION AND ITS POTENTIAL IMPACT ON THE RETIREMENT INCOMES OF BOOMERS
}

\author{
Barbara A. Butrica, Howard M. Iams, Karen E. Smith, and Eric J. Toder* \\ CRR WP 2009-2 \\ Released: January 2009 \\ Draft Submitted: December 2008
}

Center for Retirement Research at Boston College

Hovey House

140 Commonwealth Avenue

Chestnut Hill, MA 02467

Tel: 617-552-1762 Fax: 617-552-0191

\begin{abstract}
* Barbara A. Butrica is a senior research associate at the Urban Institute. Howard M. Iams is a data and modeling expert at the Social Security Administration. Karen E. Smith is a senior research associate at the Urban Institute. Eric J. Toder performs and supervises research on tax policy and retirement policy at the Urban Institute and UrbanBrookings Tax Policy Center. The research reported herein was pursuant to a grant from the U.S. Social Security Administration (SSA) funded as part of the Retirement Research Consortium (RRC). The findings and conclusions expressed are solely those of the authors and do not represent the views of SSA, any agency of the Federal Government, the RRC, Boston College, or the Urban Institute.

The authors gratefully acknowledge the expert team of researchers that have developed MINT over the past decade. These include, but are not limited to, Karen Smith, Eric Toder, Melissa Favreault, Gary Burtless, Stan Panis, Caroline Ratcliffe, Doug Wissoker, Cori Uccello, Tim Waidmann, Jon Bakija, Jillian Berk, David Cashin, Matthew Resseger, and Katherine Michelmore.
\end{abstract}

(C) 2009, by Barbara A. Butrica, Howard M. Iams, Karen E. Smith, and Eric J. Toder. All rights reserved. Short sections of text, not to exceed two paragraphs, may be quoted without explicit permission provided that full credit, including (C) notice, is given to the source. 


\title{
About the Center for Retirement Research
}

The Center for Retirement Research at Boston College, part of a consortium that includes parallel centers at the University of Michigan and the National Bureau of Economic Research, was established in 1998 through a grant from the Social Security Administration. The Center's mission is to produce first-class research and forge a strong link between the academic community and decision makers in the public and private sectors around an issue of critical importance to the nation's future. To achieve this mission, the Center sponsors a wide variety of research projects, transmits new findings to a broad audience, trains new scholars, and broadens access to valuable data sources.

\author{
Center for Retirement Research at Boston College \\ Hovey House \\ 140 Commonwealth Avenue \\ Chestnut Hill, MA 02467 \\ phone: 617-552-1762 fax: 617-552-0191 \\ e-mail: crr@bc.edu \\ www.bc.edu/crr
}

Affiliated Institutions:

The Brookings Institution

Massachusetts Institute of Technology

Syracuse University

Urban Institute 


\begin{abstract}
The long-term shift in coverage from defined benefit (DB) pensions to defined contribution (DC) plans may accelerate rapidly as more large companies freeze their DB pensions and replace them with new or enhanced DC plans. This paper uses the Model of Income in the Near Term to simulate the impact of an accelerated transition from DB to DC pensions on the distribution of retirement income among boomers. A scenario in which employers freeze all remaining private sector DB plans and a third of all state and local plans over the next five years will on balance produce more losers than winners among boomers and reduce their average incomes at age 67. Income changes will be largest among higher-income boomers, who have the highest DB coverage rates and projected pension incomes. Furthermore, the numbers of winners and losers and net income changes are much greater for the last wave of boomers (born between 1961 and 1965) than for earlier boomers. Younger boomers are most likely to have their DB pensions frozen with relatively little job tenure and to lose their high accrual years for DB pension wealth, but also to have relatively more years to accumulate DC pension wealth before retirement.
\end{abstract}

More than any other birth cohort, the boomer cohorts face increased risks from an accelerated shift from DB to DC pensions. Individual outcomes will depend on the magnitude of DB pension losses, participation and contribution rates in the new DC pension plans, and investment returns on retirement account assets. While most boomers will experience modest changes in income, an accelerated decline in DB coverage will reduce incomes by at least 5 percent for about 10 percent of last wave boomers. 


\section{Introduction}

The percentage of workers covered by a traditional defined benefit (DB) pension plan that pays a lifetime annuity, often based on years of service and final salary, has been steadily declining over the past 25 years. Between 1980 and 2008, the proportion of private wage and salary workers participating in DB pension plans fell from 38 to 20 percent (U.S. Bureau of Labor Statistics 2008; U.S. Department of Labor 2002). In contrast, the percentage of workers covered by a defined contribution (DC) pension plan- that is, an investment account established and often subsidized by employers, but owned and controlled by employees—-has been increasing over time. Between 1980 and 2008, the proportion of private wage and salary workers participating in only DC pension plans increased from 8 to 31 percent (U.S. Bureau of Labor Statistics 2008; U.S. Department of Labor 2002). More recently, many employers have frozen their DB plans (Munnell et al. 2006). Some experts expect that most private sector plans will be frozen in the next few years and eventually terminated (Gebhardtsbauer 2006). Under the typical DB plan freeze, current participants will receive retirement benefits based on their accruals up to the date of the freeze, but will not accumulate any additional benefits, and new employees will not be covered. Instead, employers will either establish new DC plans or increase contributions to existing plans.

These trends threaten to shake up the American retirement system as we know it because of vast differences between DB and DC pension plans, including differences in coverage rates within a firm, timing of accruals, investment and labor market risks, forms of payout, and effects on work incentives and labor mobility. DB pensions are tied to employers who, consequently, bear the responsibility for ensuring that employees receive pension benefits. In contrast, DC 
retirement assets are owned by employees who, therefore, bear the responsibility for their own financial security.

This paper simulates how the shift from DB to DC pensions might affect the distribution of retirement income among boomers under two different pension scenarios: one that maintains current DB pensions and one that freezes all remaining DB plans and a third of all state and local plans over the next five years. The analysis uses the Social Security Administration's (SSA) Model of Income in the Near Term (MINT) microsimulation model to describe the potential impact of the pension shift on boomers at age 67. The paper examines both changes in retirement income and numbers of winners and losers, and compares these outcomes among individuals grouped by sex, educational attainment, marital status, race/ethnicity, years of paid employment, and quintiles of lifetime earnings and retirement income. Of principal concern is whether income from increased DC plan coverage will compensate for the loss of DB plan benefits.

\section{Background}

There are two general types of pensions: DC plans and traditional DB plans. In DC plans, which include 401(k) plans, employers, employees, or both employers and employees make taxdeferred contributions to a retirement account in the employee's name. The contribution amount can be set either as a particular share of salary or a given dollar amount. At retirement, workers receive the funds that have accumulated in their accounts, generally as lump-sum distributions (Johnson, Burman, and Kobes 2004), although they can also use the proceeds to purchase annuities in the marketplace.

Traditional DB plans provide workers with guaranteed lifetime annuities that begin at retirement and promise benefits that are typically expressed as a multiple of years of service and 
earnings received near the end of one's career (e.g., 1 percent of average salary received during the final three years on the job times the number of years of service). Plan participants cannot collect benefits until reaching the plan's retirement age, which varies among employers. Some plans allow workers to collect reduced benefits at specified early retirement ages.

The value of future retirement benefits from DC plans increases each year by the value of employee and employer contributions to the plan plus any investment returns earned on the account balance. As long as market returns are relatively stable and participants and their employers contribute consistently over time, account balances will increase steadily each year until retirement.

The growth pattern of future benefits is by design more erratic in DB plans, and can even decline at older ages. Pension wealth — the present discounted value of the stream of future expected benefits-grows slowly in typical DB plans for young workers, but increases rapidly once workers approach the plan's retirement age. Pension wealth is minimal at younger ages because junior employees typically earn low wages and have completed only a few years of service. In addition, if a worker terminates employment with the firm, benefits at retirement are based only on earnings to date and their present value is low because the worker receives them many years in the future. The present value of DB benefits rises rapidly as workers increase tenure with their current employer, their earnings increase through real wage growth and inflation, and they approach the time when they can collect benefits. Workers in traditional DB plans often lose pension wealth, however, if they stay on the job beyond a certain age or seniority level. Growth in promised annual retirement benefits typically slows at older ages as wage growth declines. Some plans also cap the number of years of service that workers can credit toward their pensions, and others cap the share of pre-retirement earnings that the plan will 
replace in retirement. In addition, pension wealth can decline for workers who remain on the job past the plan's retirement age if the increase in annual benefits from an additional year of work is insufficient to offset the loss due to a reduction in the number of pension installments. As a result, traditional DB plans often create a strong disincentive to continue working for the same employer at older ages.

For the past quarter of a century the occupational pension structure in the United States has been shifting from DB to DC plans (Buessing and Soto 2006; Copeland 2006; Wiatrowski 2004). Munnell and Sunden (2004) attribute the pension shift to changes in the economy, increased regulation of DB plans, and employee preferences for portable savings account balances and a sense of control over their savings. The shift began in the early 1980s after IRS regulations implemented a provision of the 1978 Revenue Act that allowed employees to make voluntary contributions to employer-sponsored retirement plans with pretax dollars. ${ }^{1}$ Since then, the adoption of DB pension plans by new businesses has virtually halted, and has been replaced by the adoption of 401(k)-type pension plans that permit voluntary employee contributions (Munnell and Sunden 2004). The employment sector shift away from manufacturing and towards service and information technology also decreased the availability of DB plans, as new firms in growing sectors of the economy adopted DC plans instead (Wiatrowski 2004). More recently, accounting changes that require corporate financial statements to recognize the future obligations from retirement plans have accelerated the shift away from DB plans, as employers seek to reduce the volatility of reported earnings (Burkholder and Lugo 2007; Schieber 1999; Wyand 2006).

\footnotetext{
${ }^{1}$ Prior to 1978 , employees could make voluntary contributions to thrift saving plans established by employers; interest accruals within the plans were tax-free until withdrawal, but the contributions were not deductible. Contributions by employers to DC plans were tax-exempt, but employees did not have the option of making voluntary tax-deductible contributions.
} 
The future of pensions is uncertain as even employers with financially healthy DB plans consider whether to eliminate them over time. By December 2006, many American companies had instituted "freezes" in their DB pensions and replaced them with new or enhanced DC pensions (Smith et al. 2007; Vanderhei 2007). The Pension Protection Act of 2006 may have fueled this trend by increasing the financial requirements for DB pensions, making permanent the increases in DC contribution limits in the 2001 tax cuts, and facilitating the use of default participation rules in DC plans (AARP 2007; The Center on Federal Financial Institutions 2006). In 2007, a survey of private sector DB plan sponsors by Mercer and the Employee Benefits Research Institute (EBRI) found over a third of DB sponsors had recently frozen their DB pension plans and a third of the remaining employers expected to freeze or close their plans in the next two years (Vanderhei 2007). Some experts expect that most private sector plans will be frozen or terminated within the next few years (Gebhardtsbauer 2006). This is essentially what happened in the United Kingdom. When the British adopted transparent financial accounting standards and the government taxed "excess" pension plan accumulations, the level of assets "in terminated or frozen status” increased from 35 percent in 1998 to 70 percent in 2006 (Munnell and Soto 2007).

\section{Methodology}

Our analysis is based on projections of the major sources of retirement income from the Social Security Administration’s microsimulation MINT model. SSA’s Office of Research, Evaluation, and Statistics developed MINT with substantial assistance from the Brookings Institution, the RAND Corporation, and the Urban Institute. Starting with data from the 1990 to 1993 and 1996 panels of the United States Census Bureau’s Survey of Income and Program 
Participation (SIPP) matched to the Social Security Administration's (SSA) earnings and benefit records through 2004, MINT projects the future life course of persons born between 1926 and 1965. MINT independently projects each person's marital changes, mortality, entry to and exit from Social Security disability insurance (DI) rolls, and age of first receipt of Social Security and pensions benefits. It also projects family income including Social Security benefits, pension income, asset income, earnings, Supplemental Security Income, income from non-spouse coresident family members, and imputed rental income. ${ }^{2}$

MINT directly measures the experiences of survey respondents as of the early 1990s— representing the first third to the first half of the lives of boomers — and changes in earnings and Social Security benefits through 2004 using SSA Administrative records. MINT then projects individuals' characteristics and incomes into the future until death, accounting for major changes in the growth of economy-wide real earnings, the distribution of earnings both between and within birth cohorts, and the composition of the retiree population. All these factors will affect the retirement income of future boomer retirees. ${ }^{3}$ The projections in this paper are based on MINT5. ${ }^{4}$ More detail on the MINT model can be found in appendix A and in Smith et al. (2007).

\footnotetext{
${ }^{2}$ Imputed rental income is the return that homeowners receive from owning instead of renting, in the form of reduced rent, less costs of homeownership. It is estimated as a 3.0 percent real return on home equity (the difference between the house value and the remaining mortgage principal).

${ }^{3}$ MINT5 uses projections by the Social Security Administration's Office of the Chief Actuary (OCACT) of net immigration, disability prevalence through age 65 , mortality rates, and the growth in average economy-wide wages and the consumer price index (CPI) from the intermediate cost scenario in the 2008 Old Age, Survivors, and Disability Insurance (OASDI) Trustees Report (U.S. Board of Trustees 2008).

${ }^{4}$ Updated with 2008 Board of Trustees assumptions and technical corrections, November 2008 (MINT5exV5HIGH and MINT5exV5LOW).
} 


\section{Projecting Pensions in MINT}

MINT projects employer-sponsored DB, DC, and cash balance (CB) pension plans. ${ }^{5}$ Pension benefits are based on an individual's entire work history (real and simulated) up to the projected retirement date. SIPP self-reported data provide baseline information about pension coverage on current and past jobs. The MINT baseline was recently updated to reflect pension plan structures through December 2006, including DB pension plan freezes and conversions to CB plans. The pension module uses data from the PENSIM ${ }^{6}$ model to impute future job changes and pension coverage on future jobs from the time of the SIPP interview through age 50. After age 50, the pension module assumes that no further job changes take place.

With each job separation, MINT projects that some workers cash out their accumulated DC balances. The probability of cashing out is higher for younger than for older workers and higher for workers with low account balances than for those with high account balances. Vested workers take up DB benefits at the latter of the plan's early retirement age or projected retirement age. Workers selecting a joint and survivor pension receive a reduced benefit with a 50 percent survivor annuity. MINT randomly assigns a cost of living adjustment (COLA) to pensions. See Toder et al. (2002) for more details about the treatment of COLAs in the MINT pension module.

\footnotetext{
${ }^{5}$ Cash balance (CB) plans are a hybrid type of pension plan in which employers guarantee rates of return, as in a DB plan, but the employee receives a separate account that increases in value from both employer contributions and the plan rate of return, as in a DC account.

${ }^{6}$ PENSIM is a microsimulation model developed by Martin Holmer of the Policy Simulation Group. PENSIM is used for the analysis of the retirement income implications of government policies affecting employer-sponsored pensions. The PENSIM projections of employee pension coverage are calibrated by worker age, broad industry group, union status, and firm size to the 2008 National Compensation Survey.
} 
MINT projects DC pension participation and contributions using the 1996 SIPP matched to the Social Security Administration’s Detailed Earnings Records (DER). ${ }^{7}$ DC pension participation is estimated using a logit model. Separate models of the probability of participation are estimated for those who contributed to a plan in the previous year and those who did not contribute. DC contributions are estimated using a random effects Tobit model. This model allows for both an individual permanent and random error. It also controls for the statutory annual contribution limit.

The share of account balances and contributions allocated to stocks and bonds varies by age, on the basis of EBRI/Investment Company Institute (ICI) data. Every five years, the model rebalances the portfolios according to the allocation strategy for the individual's attained age category. Subsequent contributions match the allocation strategy of the attained age, if different.

MINT accumulates DC account balances from the time of the SIPP survey to 2005 using historical price changes and historical returns for stocks, long-term corporate bonds, and longterm government bonds. MINT assumes a real rate of return for stocks of 6.5 percent, a real rate of return for corporate bonds of 3.5 percent, and a real rate of return for government bonds of 3.0 percent. Rates of return for individuals are varied assuming a standard deviation of 17.28 percent for stocks and 2.14 percent for bonds. In every year, 1 percent is subtracted from each of the stock and bond real rates of return to reflect administrative costs.

MINT projects DB pensions using the Pension Benefit Guaranty Corporation’s (PBGC) Pension Insurance Modeling System (PIMS) DB plan formulas, which are randomly assigned to DB participants based on broad industry, union status, and firm size categories, and an indicator

\footnotetext{
${ }^{7}$ The DER includes longitudinal values for taxable and deferred earnings based on IRS W-2 forms from 1992 to 2004.
} 
of whether the firm offers dual (DB and DC) coverage. ${ }^{8}$ MINT uses actual benefit formulas to calculate benefits for federal government workers and military personnel, and uses tables of replacement rates from the U.S. Bureau of Labor Statistics (BLS) to calculate replacement rates for state and local government workers. The model projects conversions of pension plan type (from DB to CB or DB to DC) using actual plan change information for plans included in the PIMS data.

If a worker is assigned to a plan that freezes, DB pension accruals stop as of the freeze date. The pension module assumes that all firms with jointly offered DB and DC plans increase the employer match provisions of the existing plan and that all firms with stand-alone plans offer a substitute DC plan. ${ }^{9}$ In the first year of a DB plan freeze, DC pension participation is estimated using the model for those who contributed to a DC pension in the previous year. That is, the pension module treats workers in the first of the freeze as though they had previously contributed to a DC pension and maintains their tenure. After the first year of the freeze, DC pension participation is estimated using either the model for those who contributed to a DC pension in the previous year or the model for those who did not contribute. Workers are assigned to one of these two models based on their predicted probability of participating in a DC pension in the first year of the freeze.

MINT uses the 1997 to 2003 Form 5500 public use data to identify DB plans that converted to CB plans over that time period. Workers are assigned CB plans based on the transition provisions described in the summary plan description (SPD). If a worker is grandfathered in, the worker retains the existing DB plan. If a worker is offered a choice, the

\footnotetext{
${ }^{8}$ PIMS is a model developed by the PBGC. It contains data for a sample of DB plans (but lacks CB plans). The model estimates future pension costs that must be borne by PBGC due to the bankruptcies of firms with DB plans.

${ }^{9}$ The pension module assigns the actual DC provisions of the plan if it is known. Otherwise, DC plans parameters are imputed based on the distribution of known plans.
} 
pension module calculates the expected DB and CB benefit at the date of the conversion and assigns the worker the plan type that offers the higher expected benefit. Workers that join the firm after the conversion date are assigned the CB plan. At retirement, all CB accruals are paid out as a lump sum, which is added to other retirement account assets.

\section{Measuring Income in Retirement from DB Pension Plans and Retirement Accounts}

MINT computes income from financial assets by determining the real (price-indexed) annuity a family could buy if it annuitized 80 percent of the total savings amount. The annuity value calculated is used for that year's imputation of income from financial assets only. The annuity is recalculated each year to reflect changes in wealth amounts, based on the model of wealth spend-down, and changes in life expectancy, given that the individual lived another year. For married couples, MINT assumes a 50 percent survivor annuity.

We measure income from financial wealth and retirement accounts as annuities in order to ensure comparability with DB pension and Social Security benefits, which are also annuities. Without this adjustment, MINT would overstate the loss in retirement well-being due to the shift from DB pension income to DC assets because one dollar in DB pension wealth produces more measured income than one dollar in DC wealth. We do, however, discount the annuity return by 20 percent to reflect the fact that people cannot necessarily purchase actuarially fair annuities and, if they choose to spend down their wealth outside of annuities based on life expectancy, run the risk of depleting their assets if they live longer than expected.

This income measure differs conceptually from asset income as measured by the U.S. Census Bureau and other analysts, which includes only the rate of return on assets (interest, dividends, and rental income) and excludes the potential consumption of capital that could be 
realized if a person spent down her wealth. The U.S. Census Bureau and many analysts include this consumption of capital from retirement accounts only if people choose regularly to withdraw money from the accounts, while MINT treats 80 percent of the annuity value as income without regard to how much is actually withdrawn.

\section{Pension Simulations}

We test whether the distribution of economic well-being at age 67 significantly differs between the MINT baseline pension scenario and the previously discussed British pension scenario. The baseline scenario represents the United States pension structure, including known pension plan freezes as of the end of $2006 .{ }^{10}$ It maintains current employer plans, but permits DB and DC coverage to evolve over time with changes in the composition of employment and in factors influencing workers’ DC plan participation and contribution rates. The alternative scenario represents the British pension structure, which we refer to as the "UK scenario", and assumes that all private sector DB pensions and a third of public sector DB pensions will be frozen within five years. In each year between 2007 and 2011, an additional 20 percent of firms are randomly simulated to freeze their DB plans. We assume that employers who freeze their plans will either establish a DC plan, if none exists, or increase contributions to their existing plan.

The UK scenario will have little effect on boomer DB coverage, but will affect DB accruals. Current employees will not lose their DB coverage, but will have less pension wealth at retirement because their pensions will be based on their accruals only up to the time of the freeze. Because frozen plans are closed to new employees, however, workers who are projected

\footnotetext{
${ }^{10}$ See Smith et al. (2007) table 8.9 for a list of the 25 baseline frozen pension plans and characteristics of the replacement DC plans.
} 
to start new jobs with DB pensions under the baseline will lose DB coverage under the simulated pension freezes. For the most part, only these job changers will see their DB coverage status change under the option. (Some existing employees who are not vested in a plan, however, gain DB coverage they otherwise would not have because all existing employees become vested under a pension freeze.)

We analyze the characteristics and family income of individuals born in the boomer cohort when they reach age 67 (the age by which most people will have retired). We assume husbands and wives share resources within the family. All reported income projections are in annual per capita 2007 dollars. Since our sample sizes are large (over 100,000 records), differences between most variables in the simulations will be statistically significant.

Because the boomer cohort includes individuals born over a 19-year period, the pension freezes will affect its members differently. The oldest boomers, who are near or at retirement age when the first new plan freezes occur in 2007, will have their DB pensions frozen with lengthy job tenures causing them to lose only a few high benefit-accrual years, but will also have relatively few years to boost their DC account balances before retirement. The youngest boomers, who will be under age 50 when the last projected new plan freezes occur in 2011, will have their DB pensions frozen with relatively little job tenure and lose many years of DB wealth accrual, but will also have relatively more years to accumulate DC pension wealth before retirement. To understand better the differential impact of DB pension freezes on the retirement incomes of boomers, we report results separately for four waves of boomers born between 1946 and1950, 1951 and 1955, 1956 and 1960, and 1961 and $1965 .^{11}$

\footnotetext{
${ }^{11}$ Boomers are typically represented as those born between 1946 and 1964. For analytical purposes, however, we define the boomer cohort as those born between 1946 and 1965.
} 


\section{Results}

\section{Characteristics of Boomer Retirees}

Boomers in the last wave (1961-1965 birth cohorts) are nearly twice as likely as their earlier counterparts to be Hispanic, and are less likely to be college educated (table 1). For example, 14 percent of last wave boomers are Hispanic compared with only 8 percent of first wave (1946-1950 birth cohorts) boomers, and only 28 percent of last wave boomers are college graduates compared with 32 percent of first wave boomers. Relative to first wave boomers, last wave boomers are also less likely to be married at age 67 and more likely to be never married or divorced. Cohort differences are important because pension coverage varies significantly by race/ethnicity and education.

\section{Projected Sources of Retirement Incomes under the Baseline and UK Scenarios}

Among the first wave of boomers, 85 percent are expected to have income from financial assets and 48 percent will have earnings, either their own or their spouse’s (table 2). Only 3 percent of individuals are projected to receive SSI benefits, but 85 percent will have imputed rental income from homeownership and 94 percent will receive Social Security benefits. Under the baseline, 50 percent of first wave boomers are projected to have family DB pension benefits and 76 percent are projected to have retirement accounts. Pension coverage does not change under the UK scenario for first wave boomers because no one who had DB coverage before the freeze loses their coverage (though, as we show below, their benefits are reduced), and because first wave boomers are near or at retirement age and are less likely than younger workers to take up DC pensions when newly offered. 
Compared with the first wave of boomers, the last wave of boomers are slightly more likely to have income from assets (86 versus 85 percent), but less likely to have earnings (42 versus 48 percent). Under the baseline, last wave boomers are 6 percentage points less likely than first wave boomers to have DB pension benefits (compare 44 with 50 percent), but are slightly more likely to have retirement accounts (compare 77 with 76 percent). The UK scenario accelerates the shift from DB to DC pensions, reducing the share of last wave boomers with DB pensions by an additional 2 percentage points and increasing the share with retirement accounts by 2 percentage points, compared with the baseline. Freezing more DB plans does not cause many boomers to lose DB coverage because all workers with existing DB plans retain them, even though they stop accruing benefits, and some workers who are not vested gain coverage. Only workers with no previous DB coverage who take new jobs subject to a simulated hard freeze under the UK scenario have DB coverage in the baseline, but not under the UK scenario. The UK scenario also increases the numbers with DC coverage only slightly because many of the affected workers already had DC coverage from their prior or current job.

Under the baseline, average per capita family DB pension benefits are projected to decline over time from $\$ 5,100$ for first wave boomers to $\$ 3,000$ for last wave boomers, while income from retirement accounts is projected to increase over time from $\$ 6,200$ for first wave boomers to $\$ 7,700$ for last wave boomers (table 3). For boomers in the first wave, average per capita family DB pension benefits are expected to be only about $\$ 200$ lower under the UK scenario than under the baseline, and average income from retirement accounts increases by less than $\$ 100$. For boomers in the last wave, average per capita family DB pension benefits are expected to be about $\$ 1,100$ lower under the UK scenario than under the baseline, and average income from retirement accounts is projected to be about $\$ 300$ more. Over time, the decline in 
DB pension benefits and the increase in income from retirement accounts is greater under the UK scenario than under the baseline. Furthermore, under both scenarios, the decline in DB benefits is greater than the increase in income from retirement accounts. As a result, per capita family income at age 67 is about $\$ 100$ lower for first wave boomers and about $\$ 700$ lower for last wave boomers under the UK scenario than under the baseline. On average, the additional income from retirement accounts under the UK scenario replaces only part of the lost income from DB pensions. This is largely because the pension freezes deprive boomers, especially those in the last wave, of their high accrual years for DB pension wealth and the replacement DC plan does not generate assets large enough to replace the lost DB wealth.

\section{Subgroups Differences in Projected Retirement Outcomes}

The impact of the simulations on different demographic groups will depend on whether they typically have pension benefits. Individuals who are married, non-Hispanic white, and college educated, have more experience in the labor force, and are in the highest shared lifetime earnings and retirement income quintiles are most likely to have DB pensions and retirement accounts (table 4). ${ }^{12}$

Demographic groups most likely to have pensions also have higher average family incomes and are projected to be most affected by the pension shift. Under the baseline, mean family income per person is highest for men, married adults, non-Hispanic whites, college graduates, those with 30 or more years of labor force experience, and those in the top quintile of shared lifetime earnings - in every boomer wave (table 5). Both the absolute and percentage declines in average family income per person between the baseline and UK scenarios are largest

\footnotetext{
${ }^{12}$ Our earnings measure is "shared lifetime earnings"- the average of wage-indexed shared earnings between ages 22 and 62, where shared earnings are computed by assigning each individual half the total earnings of the couple in the years when the individual is married and his or her own earnings in years when unmarried.
} 
for many of these same groups (table 6). For the last wave boomers, however, non-Hispanic blacks experience the largest percentage decline in income among racial groups, non-married individuals experience greater percentage declines in income than married individuals, and females experience a slightly larger percentage decline in income than males. Still, the overall percentage declines in income are much greater in the highest than in the lowest quintiles of individuals ranked either by shared lifetime earnings or retirement income at age 67.

\section{Who Are the Winners and Losers?}

The accelerated switch from DB to DC plans illustrated in the UK scenario produces both losers and winners. Many boomers will lose under the UK scenario, particularly mid- and latecareer employees whose pension benefits will be frozen before reaching their highest accrual rate, those who contribute little or nothing to DC plans, and those who contribute more to retirement accounts that experience market losses. Others, however, may gain from the shift from DB to DC plans, especially those who currently fare poorly under DB plans because they have intermittent work histories or change jobs frequently and those with high rates of return on their retirement account investments.

Our simulations show the losers greatly outnumber the winners (table 7 ) ${ }^{13}$ When the shift from DB to DC pensions is accelerated under the UK scenario, only 7 percent of first wave boomers, 8 percent of second wave boomers, 9 percent of third wave boomers, and 11 percent of last wave boomers would see their retirement incomes increase. There are many more who would lose under the UK scenario-12 percent of first wave boomers, 18 percent of second wave boomers, 22 percent of third wave boomers, and 26 percent of last wave boomers. Boomers in

\footnotetext{
${ }^{13}$ We define winners and losers as those with at least a $\$ 10$ change in their per capita family income at age 67 between the baseline and UK scenarios.
} 
high socio-economic groups are most likely both to win and lose, because they are the people with pension benefits in the baseline scenario that may potentially be frozen. For example, 12 percent of last wave boomers in the highest income quintile are projected to be winners compared with only 6 percent of their counterparts in the lowest income quintile, and 48 percent of last wave boomers with the highest incomes are projected to be losers compared with only 8 percent of those with the lowest incomes (figure 1). All in all, 60 percent of last wave boomers in the highest income quintile will experience a change (either positive or negative) in their per capita family income due to the change in pension schemes. Note that the percentage affected is higher than the 54 percent of last wave boomers in the highest income quintile who are projected to have family DB pension benefits in the baseline scenario (see table 4). This apparent discrepancy occurs because some workers who are not vested under the baseline scenario become immediately vested under a pension freeze, thereby gaining DB pension income. Many of these people who newly gain pension coverage may have previously changed jobs or dropped out of the labor force at a relatively young age due to a disability. ${ }^{14}$

It is also worth noting that among last wave boomers, there are about four times as many losers than winners in the highest income quintile, but only slightly more losers than winners in the lowest quintile. High income workers are significantly more likely than low income workers to lose under the UK scenario because they are more likely to be constrained by the statutory contribution thresholds in 401(k) plans, which limit their ability to replace lost DB pension wealth. These thresholds will increase in the future with changes in prices per the Pension Protection Act of 2006. Because wages are projected to increase faster than prices, however,

\footnotetext{
${ }^{14}$ We measure winners and losers by looking at the change in total family income at age 67 . A small percentage of DB recipients do not begin collecting DB pensions until after age 67. These recipients could ultimately end up as losers even when our table shows them as winners because their DB benefits, when they start collecting them, will be smaller under the UK scenario than under the baseline. The vast majority of DB beneficiaries, however, are already collecting benefits by age 67 .
} 
later cohorts of workers will be more constrained by the statutory contribution thresholds in 401(k) plans than earlier cohorts and these constraints will mostly affect higher-income workers who are the ones far most likely to contribute the maximum. Furthermore, many DB plans provide higher accrual rates for workers with earnings above the Social Security taxable maximum, so the loss of DB benefits is also especially high for some high-income workers. These highly-compensated workers who are affected by DB pension freezes replace their relatively generous DB plan with a more constrained DC plan.

The percentage of those who lose relatively large amounts of income under the UK scenario is also concentrated among the highest income quintiles. The UK scenario reduces income at age 67 by 5 percent or more for 15 percent of last wave boomers in the top income quintile, but only 3 percent of those in the bottom quintile (figure 2). In contrast, the share of large winners is fairly evenly distributed among income quintiles. The population subgroups least likely to gain large amounts of income under the UK scenario are high school dropouts, those with less than 20 years of labor force experience, and those in the bottom quintile of lifetime earnings (table 8).

The amount that winners gain and losers lose increases over time as the accelerated change from DB to DC pension schemes affects more last wave boomers. Among winners, average per capita family incomes are projected to increase by $\$ 2,100$ for first wave boomers and $\$ 2,800$ for last wave boomers. Among losers, average per capita family incomes are projected to decline by $\$ 2,600$ for first wave boomers and $\$ 4,200$ for last wave boomers (table 9). ${ }^{15}$ Boomers in high socio-economic groups, who most are likely to have pensions and who have the most benefits at risk, are projected to experience the largest gains and losses. For example, average per

\footnotetext{
${ }^{15}$ Appendix table B1 shows the percent change in per capita income for winners and losers for the same subgroups as Table 9.
} 
capita family income among winners in the last wave of boomers is projected to increase by about $\$ 5,800$ for those with the highest incomes, but by only about $\$ 800$ for those with the lowest incomes. In comparison, average per capita family income among losers in the last wave of boomers is projected to decline by about $\$ 8,000$ for those with the highest incomes, but by only about $\$ 700$ for those with the lowest incomes.

\section{What's Driving the Outcomes?}

Retirement incomes may increase under the UK scenario for several reasons. First, some workers may increase their DC contributions or earn above average returns on their retirement accounts, boosting their wealth relative to what they would accrue in DB plans. Second, some workers increase accruals in DB accounts because they become vested when plans are frozen. ${ }^{16}$ Third, some workers whose DB plans are frozen or who never acquire DB coverage may delay retirement and work longer because DC pensions, unlike DB pensions, do not encourage early retirement (Butrica, Johnson, Smith, and Steuerle 2006). Indeed, we find that winners are projected to have higher per capita family earnings and Social Security benefits under the UK scenario than under the baseline due to delayed retirement.

Overall, winners among first and second wave boomers experience increases in income from both DB pensions and retirement accounts. In contrast, winners among third and last wave boomers experience losses in their DB pensions and increases in their retirement accounts, with income losses in DB pensions being much smaller than income gains in retirement accounts (table 10).

\footnotetext{
${ }^{16}$ Some workers may also receive higher DB benefits after the freeze because of an increase in the earnings the plan replaces. This can happen if the pension replaces the average of the last five years of covered earnings and a higherearning year before the freeze substitutes for a lower-earning year after the freeze.
} 
For those whose family incomes decline under the UK scenario, the reduction is driven almost totally by a reduction in DB benefits. Losers experience much larger DB pension losses under the UK scenario than winners, but have very modest increases in income from retirement account balances compared with winners. Compared with winners, losers have much more retirement wealth under the baseline and so have much more to lose from a change in pension coverage. Their average per capita family DB pensions range from 1.4 to 2.5 times higher than those of winners, but they are also projected to have average per capita family retirement accounts that are 1.2 to 1.3 times higher than those of winners. For all boomers projected to lose income, the increase in retirement accounts offsets less than six percent of the decline in DB pension benefits. This huge ratio of DB benefit losses to DC benefit gains could occur for a variety of reasons, including the loss of high accruing years in DB plans, low participation or contribution rates in the new retirement accounts, or lower than average investment returns on retirement account assets. ${ }^{17}$

\section{Conclusions}

In recent years, the United States has seen a significant shift away from defined benefit pension plans to defined contribution plans. This shift may accelerate rapidly, as more large companies, even those with financially solvent plans, freeze their defined benefit plans and replace them with new or enhanced defined contribution plans. A dramatic shift away from defined benefit plans, as has happened in the United Kingdom, would produce both losers and winners among future boomer retirees. On balance, there would be more losers than winners and average family incomes would decline. The decline in family income is expected to be much

\footnotetext{
${ }^{17}$ Appendix table B2 shows mean family income at age 67 by income source for individuals that gain less than 2 percent, 2 to 5 percent, and 5 percent or more. Appendix table B3 shows the same information for losers.
} 
larger for last wave boomers born between 1961 and 1965 than for first wave boomers born between 1946 and 1950 because last wave boomers are more likely to have their DB pensions frozen with relatively little job tenure. We project that 26 percent of last wave boomers would have lower family incomes at age 67 and 10 percent of them would experience at least a 5 percent decline. While retirement incomes would increase for some families under the alternative pension scenario, only 11 percent of the last wave boomers would see their income increase and only 3 percent would experience a gain of 5 percent or more.

Demographic groups most likely to have pensions under the baseline scenario are projected to be those most affected by the accelerated freezing of DB plans, namely nonHispanic whites, college graduates, those with many years of work experience, and those in the highest lifetime earnings and retirement income quintiles. Because the groups most likely to have DB plans have the most income at risk but also the largest potential gains from substituting DB pensions with additional DC wealth, they are projected to experience both the largest losses and the largest gains from the pension transition. For example, average per capita family income among losers in the last wave of boomers is projected to decline by $\$ 8,000$ for those with the highest incomes, compared with only $\$ 700$ for those with the lowest incomes. Also, average per capita family income among winners in the last wave of boomers is projected to increase by $\$ 5,800$ for those with the highest incomes, but by only $\$ 800$ for those with the lowest incomes. Last wave boomers are more likely than their predecessors to be high school dropouts, minority, and unmarried—characteristics that are associated with low earnings during working years and economic vulnerability in retirement. But these groups are less likely to have pensions in any form and therefore are much less affected by the shift from DB to DC plans. It is likely, however, that a future with fewer DB plans will generate a new class of economically vulnerable 
retirees among formerly better off retirees who were relying on their DB pension income but now, through either bad luck or poor planning, will end up with insufficient resources in retirement.

The net decline in retirement income among boomer cohorts that results from substituting frozen DB plans with DC plans is to some degree a transitory phenomenon. If people are to participate in DB and DC plans at different times during their working careers, the worst scenario for them is to hold a DB plan early in their career and a DC plan late in their career. When workers switch from DB to DC plans in mid-career, they lose the high accrual years in their DB plans and have fewer years to accumulate DC wealth. Compared with retirement outcomes under this scenario, most workers would be better off participating in either a DB or DC plan for their entire career. More than any other birth cohort, the boomer cohorts will experience the transition from DB to DC plans in mid-career and, as our simulations show, on average suffer declines in their projected retirement incomes. Gen-Xers and those who come later may fare better depending on participation rates, contribution rates, and market returns.

The build-up of retirement assets is a complex process that varies with earnings, family changes, job changes, health status, individual choices, and fluctuations in housing and stock prices, among other factors. Policymakers need to know the impact of significant shifts in pension provisions on retirement well-being so they can assess the alternative policy options of shoring-up DB plans before they disappear or letting them slowly fade away, while focusing on ways to encourage higher participation rates and sounder investment choices within DC plans. In particular, if stock market declines close to retirement age cause significant losses in retirement accounts for some investors, policymakers may want to develop mechanisms to reduce risk in retirement assets. As more workers enter retirement with assets held outside of annuities, 
policymakers could also develop options to encourage people to use their increased retirement wealth to purchase annuities instead of spending it down rapidly. Finally, as policymakers consider proposals to improve the solvency of the Social Security system, they must recognize that the shift from DB to DC pensions means that Social Security will increasingly become the only source of guaranteed lifetime benefits that most retirees can rely on. 


\section{References}

AARP. 2007. Enhancing 401(k) Value and Participation: Taking the Automatic Approach. A report for AARP prepared by Towers Perrin. June. Washington, D.C.: AARP.

Buessing, Marric and Mauricio Soto. 2006. "The State of Private Pensions: Current 5500 Data.” Issue in Brief No. 42. Chestnut Hill, MA: Center for Retirement Research.

Burkholder, Steve and Denise Lugo. 2007. "FASB Tackles Second Phase of Pensions, Other Benefits, in Major Project for 2007.” Pension and Benefits Daily. Vol 07, Number 6. January 10, 2007.

Butrica, Barbara A., Richard W. Johnson, Karen E. Smith, Eugene Steuerle. 2006. "The Implicit Tax on Work at Older Ages.” National Tax Journal. 59(2): 211-234.

The Center on Federal Financial Insitutions. 2006. "Pension Reform: Summary of Final 2006 Bill.” August 6, 2006, release. Washington, D.C.: COFFI

Copeland, Craig. 2006. "Retirement Plan Participation and Retirees' Perception of Their Standard of Living.” EBRI Issue Brief No. 289.

Gebhardtsbauer, Ron. 2006. “The Future of Defined Benefit (DB) Plans.” Keynote speech delivered at the National Plan Sponsor conference in Washington, DC on "The Future of DB Plans.” http://www.actuary.org/pdf/pension/db_rondec06.pdf.

Johnson, Richard W., Leonard E. Burman, and Deborah I. Kobes. 2004. "Annuitized Wealth at Older Ages: Evidence from the Health and Retirement Study.” Final report to the Employee Benefits Security Administration, U.S. Department of Labor. Washington, D.C.: The Urban Institute. Available at http://www.urban.org/url.cfm?ID=411000.

Munnell, Alicia H. and Mauricio Soto. 2007. "Why Are Companies Freezing Their Pensions?” CRR Working Paper No. 2007-22. Chestnut Hill, MA: Center for Retirement Research. http://crr.bc.edu/working_papers/why_are_companies_freezing_their_pensions_.html

Munnell, Alicia H., Francesca Golub-Sass, Mauricio Soto, and Francis Vitagliano. 2006. "Why Are Healthy Employers Freezing Their Pensions?” Issue in Brief No. 44. Chestnut Hill, MA: Center for Retirement Research. http://www.bc.edu/centers/crr/issues/ib_44.pdf

Munnell, Alicia H. and Annika Sunden. 2004. Coming Up Short: The Challenge of 401(k) Plans. Washington, D.C.: Brookings Institution Press.

Schieber, Sylvester J. 1999. "The Employee Retirement Income Security Act: Motivations, Provisions, and Implications for Retirement Security.” August draft for a conference on ERISA after 25 Years. Washington, D.C.: Watson Wyatt Worldwide. 
Smith, Karen E., Melissa M. Favreault, Caroline Ratcliffe, Barbara Butrica, Eric Toder, and Jon Bakija. 2007. "Modeling Income in the Near Term 5.” Final Report, SSA Contract No: 600-01-60123. Washington, DC: The Urban Institute.

Toder, Eric, Lawrence Thompson, Melissa Favreault, Richard Johnson, Kevin Perese, Caroline Ratcliffe, Karen Smith, Cori Uccello, Timothy Waidmann, Jillian Berk, and Romina Woldemariam. 2002. "Modeling Income in the Near Term: Revised Projections of Retirement Income Through 2020 for the 1931-1960 Birth Cohorts.” Final Report, SSA Contract No: 600-96-27332. Washington, DC: The Urban Institute.

U.S. Board of Trustees of the Federal Old-Age and Survivors Insurance and Disability Insurance Trust Funds. 2008. Annual Report. Washington, DC: United States Government Printing Office.

U.S. Bureau of Labor Statistics. 2008. "National Compensation Survey: Employee Benefits in the United States, March 2008." Bulletin 2715. Washington, DC: U.S. Bureau of Labor Statistics. http://www.bls.gov/ncs/ebs/benefits/2008/ownership/private/table02a.pdf

U.S. Department of Labor. 2002. "Private Pension Plan Bulletin: Abstract of 1998 Form 5500 Annual Reports.” Number 11, Winter 2001-2002. Washington, DC: U.S. Department of Labor. http://www.dol.gov/ebsa/PDF/1998pensionplanbulletin.PDF.

VanDerhei, Jack. 2007. "Retirement Income Adequacy after PPA and FAS 158: Part One_-Plan Sponsors’ Reactions.” EBRI Issue Brief no 307. Washington, DC: Employee Benefit Research Institute.

Wiatrowski, William J. 2004. "Medical and Retirement Plan Coverage: Exploring the Decline in Recent Years.” Monthly Labor Review. 127(8): 29-36.

Wyand, Michael W. 2006. "Large Companies Support Pension Plans but Are Concerned about Future, CIEBA says.” Pension and Benefits Daily. Vol 06, no. 243. 
Figure 1. Percent of Last Wave Boomers Who Win and Lose Income at Age 67

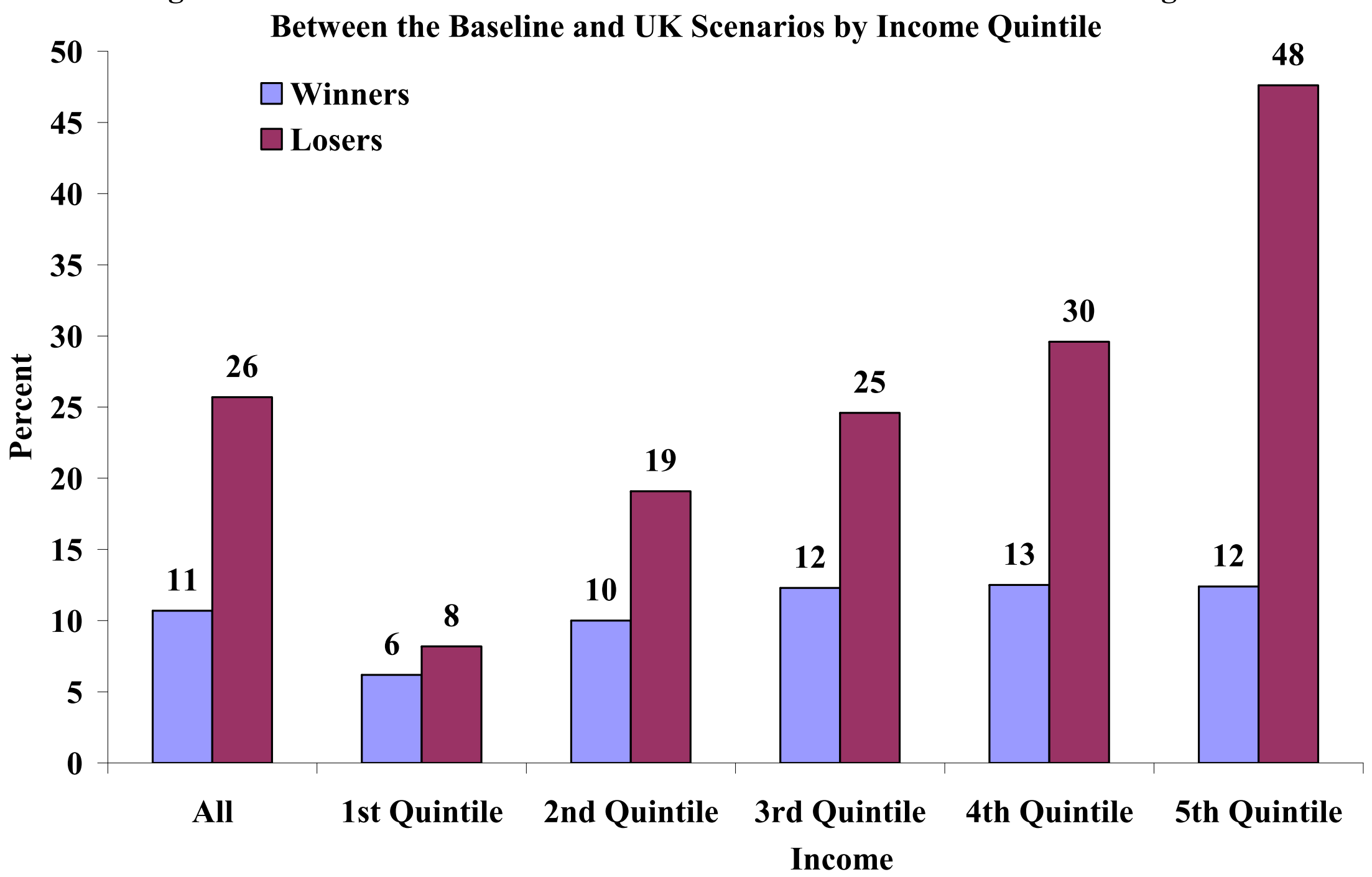


Figure 2. Percent of Last Wave Boomers Who Win and Lose Five

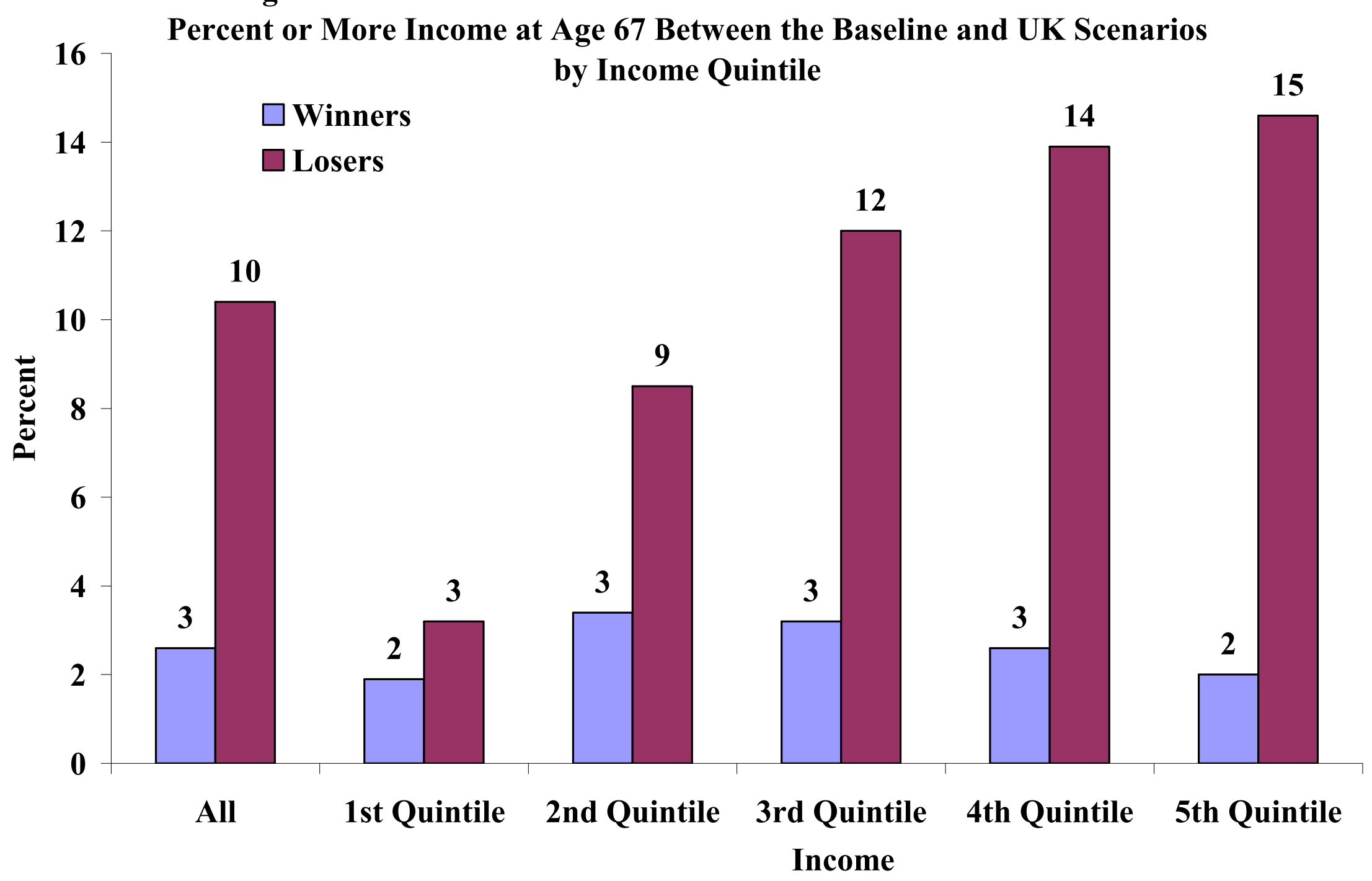


Table 1. Projected Characteristics of Individuals at Age 67 (\%)

\begin{tabular}{|c|c|c|c|c|}
\hline & $\begin{array}{c}\text { First } \\
\text { Boomers } \\
(\mathbf{1 9 4 6 - 5 0 )} \\
\end{array}$ & $\begin{array}{c}\text { Second } \\
\text { Boomers } \\
(1951-55) \\
\end{array}$ & $\begin{array}{c}\text { Third } \\
\text { Boomers } \\
(1956-60) \\
\end{array}$ & $\begin{array}{c}\text { Last } \\
\text { Boomers } \\
(1961-65)\end{array}$ \\
\hline All & 100 & 100 & 100 & 100 \\
\hline \multicolumn{5}{|l|}{ Gender } \\
\hline Female & 52 & 52 & 53 & 53 \\
\hline Male & 48 & 48 & 47 & 47 \\
\hline \multicolumn{5}{|l|}{ Marital Status } \\
\hline Never married & 5 & 6 & 7 & 8 \\
\hline Married & 67 & 65 & 63 & 62 \\
\hline Widowed & 10 & 10 & 10 & 10 \\
\hline Divorced & 18 & 19 & 20 & 21 \\
\hline \multicolumn{5}{|l|}{ Race/Ethnicity } \\
\hline Non-Hispanic white & 77 & 74 & 72 & 69 \\
\hline Non-Hispanic black & 9 & 10 & 10 & 10 \\
\hline Hispanic & 8 & 10 & 12 & 14 \\
\hline Other & 6 & 6 & 6 & 7 \\
\hline \multicolumn{5}{|l|}{ Education } \\
\hline High school dropout & 11 & 11 & 11 & 13 \\
\hline High school graduate & 57 & 60 & 61 & 60 \\
\hline College graduate & 32 & 30 & 27 & 28 \\
\hline \multicolumn{5}{|l|}{ Labor Force Experience } \\
\hline Less than 20 years & 13 & 12 & 12 & 11 \\
\hline 20 to 29 years & 10 & 11 & 11 & 12 \\
\hline 30 or more year & 77 & 77 & 77 & 77 \\
\hline
\end{tabular}

Source: Authors' computations of MINT5 (see text for details). 
Table 2. Percent of Individuals with Family Income at Age 67, by Source (\%)

\begin{tabular}{lcccc}
\hline & $\begin{array}{c}\text { First } \\
\text { Boomers } \\
(\mathbf{1 9 4 6 - 5 0 )}\end{array}$ & $\begin{array}{c}\text { Second } \\
\text { Boomers } \\
\mathbf{( 1 9 5 1 - 5 5 )}\end{array}$ & $\begin{array}{c}\text { Third } \\
\text { Boomers } \\
(\mathbf{1 9 5 6 - 6 0 )}\end{array}$ & $\begin{array}{c}\text { Last } \\
\text { Boomers } \\
(\mathbf{1 9 6 1 - 6 5 )}\end{array}$ \\
\hline Baseline & & & & \\
$\quad$ Income from Assets & 85 & 86 & 86 & 86 \\
Earnings & 48 & 44 & 42 & 42 \\
$\quad$ SSI Benefits & 3 & 2 & 2 & 2 \\
Imputed Rental Income & 85 & 85 & 84 & 83 \\
Social Security Benefits & 94 & 94 & 95 & 94 \\
DB Pension Benefits & 50 & 48 & 46 & 44 \\
Retirement Accounts & 76 & 76 & 77 & 77 \\
$\quad$ Total Income & $\mathbf{1 0 0}$ & $\mathbf{1 0 0}$ & $\mathbf{1 0 0}$ & $\mathbf{1 0 0}$ \\
UK Scenario & & & & \\
DB Pension Benefits & 50 & 48 & 46 & 42 \\
Retirement Accounts & 76 & 77 & 78 & 79 \\
Total Income & $\mathbf{1 0 0}$ & $\mathbf{1 0 0}$ & $\mathbf{1 0 0}$ & $\mathbf{1 0 0}$ \\
\hline
\end{tabular}

Note: Projections exclude individuals with family wealth in the top 5 percent of the distribution.

Source: Authors' computations of MINT5 (see text for details). 
Table 3. Mean Family Income Per Person at Age 67, by Source (in thousands, \$2007)

\begin{tabular}{lcccc}
\hline & $\begin{array}{c}\text { First } \\
\text { Boomers } \\
(\mathbf{1 9 4 6 - 5 0 )}\end{array}$ & $\begin{array}{c}\text { Second } \\
\text { Boomers } \\
(\mathbf{1 9 5 1 - 5 5 )}\end{array}$ & $\begin{array}{c}\text { Third } \\
\text { Boomers } \\
(\mathbf{1 9 5 6 - 6 0 )}\end{array}$ & $\begin{array}{c}\text { Last } \\
\text { Boomers } \\
(\mathbf{1 9 6 1 - 6 5 )}\end{array}$ \\
\hline Baseline & & & & \\
$\quad$ Income from Assets & 7.1 & 7.3 & 7.0 & 6.9 \\
Earnings & 10.7 & 9.6 & 9.2 & 9.5 \\
SSI Benefits & 0.1 & 0.1 & 0.1 & 0.1 \\
Imputed Rental Income & 3.0 & 3.0 & 2.8 & 2.8 \\
Social Security Benefits & 12.7 & 13.1 & 13.1 & 13.1 \\
DB Pension Benefits & 5.1 & 4.1 & 3.4 & 3.0 \\
Retirement Accounts & 6.2 & 6.8 & 7.5 & 7.7 \\
Total Income & $\mathbf{4 5 . 0}$ & $\mathbf{4 4 . 0}$ & $\mathbf{4 3 . 2}$ & $\mathbf{4 3 . 0}$ \\
UK Scenario & & & & \\
Income from Assets & 7.1 & 7.2 & 6.9 & 6.8 \\
Earnings & 10.8 & 9.6 & 9.3 & 9.6 \\
SSI Benefits & 0.1 & 0.1 & 0.1 & 0.1 \\
Imputed Rental Income & 3.0 & 3.0 & 2.8 & 2.8 \\
Social Security Benefits & 12.7 & 13.1 & 13.1 & 13.1 \\
DB Pension Benefits & 4.8 & 3.5 & 2.6 & 2.0 \\
Retirement Accounts & 6.2 & 6.9 & 7.6 & 8.0 \\
Total Income & $\mathbf{4 4 . 8}$ & $\mathbf{4 3 . 5}$ & $\mathbf{4 2 . 5}$ & $\mathbf{4 2 . 3}$ \\
B Baseline and UK Scenarios & & & & \\
Income from Assets & 0.0 & 0.0 & 0.0 & 0.0 \\
Earnings & 0.0 & 0.0 & 0.0 & 0.1 \\
SSI Benefits & 0.0 & 0.0 & 0.0 & 0.0 \\
Imputed Rental Income & 0.0 & 0.0 & 0.0 & 0.0 \\
Social Security Benefits & 0.0 & 0.0 & 0.0 & 0.0 \\
DB Pension Benefits & -0.2 & -0.6 & -0.9 & -1.1 \\
Retirement Accounts & 0.0 & 0.1 & 0.2 & 0.3 \\
Total Income & $\mathbf{- 0 . 1}$ & $\mathbf{- 0 . 5}$ & $\mathbf{- 0 . 7}$ & $\mathbf{- 0 . 7}$ \\
\hline
\end{tabular}


Table 4. Percent of Individuals with Family Pensions at Age 67 Under the Baseline, by Type (\%)

\begin{tabular}{|c|c|c|c|c|c|c|c|c|}
\hline & \multicolumn{4}{|c|}{ DB Benefits } & \multicolumn{4}{|c|}{ Retirement Accounts } \\
\hline & $\begin{array}{c}\text { First } \\
\text { Boomers } \\
(\mathbf{1 9 4 6 - 5 0 )} \\
\end{array}$ & $\begin{array}{c}\text { Second } \\
\text { Boomers } \\
(\mathbf{1 9 5 1 - 5 5 )} \\
\end{array}$ & $\begin{array}{c}\text { Third } \\
\text { Boomers } \\
(1956-60)\end{array}$ & $\begin{array}{c}\text { Last } \\
\text { Boomers } \\
(\mathbf{1 9 6 1 - 6 5 )} \\
\end{array}$ & $\begin{array}{c}\text { First } \\
\text { Boomers } \\
(\mathbf{1 9 4 6 - 5 0 )} \\
\end{array}$ & $\begin{array}{c}\text { Second } \\
\text { Boomers } \\
(\mathbf{1 9 5 1 - 5 5 )} \\
\end{array}$ & $\begin{array}{c}\text { Third } \\
\text { Boomers } \\
(\mathbf{1 9 5 6 - 6 0 )} \\
\end{array}$ & $\begin{array}{c}\text { Last } \\
\text { Boomers } \\
(\mathbf{1 9 6 1 - 6 5 )}\end{array}$ \\
\hline All & 50 & 48 & 46 & 43 & 75 & 75 & 76 & 76 \\
\hline \multicolumn{9}{|l|}{ Gender } \\
\hline Female & 51 & 49 & 47 & 44 & 74 & 74 & 74 & 75 \\
\hline Male & 49 & 48 & 46 & 42 & 76 & 77 & 78 & 78 \\
\hline \multicolumn{9}{|l|}{ Marital Status } \\
\hline Never married & 36 & 35 & 31 & 30 & 55 & 61 & 61 & 63 \\
\hline Married & 54 & 53 & 51 & 48 & 81 & 82 & 83 & 83 \\
\hline Widowed & 43 & 44 & 41 & 39 & 60 & 63 & 64 & 64 \\
\hline Divorced & 42 & 38 & 39 & 36 & 65 & 64 & 66 & 67 \\
\hline \multicolumn{9}{|l|}{ Race/Ethnicity } \\
\hline Non-Hispanic white & 52 & 50 & 49 & 46 & 80 & 80 & 81 & 81 \\
\hline Non-Hispanic black & 49 & 48 & 45 & 40 & 60 & 64 & 65 & 67 \\
\hline Hispanic & 38 & 39 & 37 & 35 & 51 & 58 & 61 & 65 \\
\hline Other & 37 & 38 & 34 & 37 & 63 & 64 & 66 & 71 \\
\hline \multicolumn{9}{|l|}{ Education } \\
\hline High school dropout & 29 & 29 & 29 & 28 & 40 & 44 & 48 & 49 \\
\hline High school graduate & 50 & 48 & 47 & 43 & 75 & 75 & 76 & 77 \\
\hline College graduate & 58 & 55 & 53 & 51 & 88 & 88 & 88 & 89 \\
\hline \multicolumn{9}{|l|}{ Labor Force Experience } \\
\hline Less than 20 years & 27 & 24 & 23 & 22 & 38 & 37 & 39 & 41 \\
\hline 20 to 29 years & 39 & 37 & 35 & 34 & 58 & 60 & 61 & 59 \\
\hline 30 or more year & 55 & 53 & 51 & 48 & 83 & 83 & 84 & 85 \\
\hline \multicolumn{9}{|l|}{ Shared Lifetime Earnings } \\
\hline 1st Quintile & 24 & 25 & 24 & 23 & 32 & 35 & 37 & 39 \\
\hline 2nd Quintile & 47 & 44 & 42 & 39 & 70 & 71 & 71 & 72 \\
\hline 3rd Quintile & 56 & 54 & 52 & 48 & 85 & 86 & 86 & 86 \\
\hline 4th Quintile & 62 & 62 & 57 & 55 & 93 & 92 & 92 & 93 \\
\hline 5th Quintile & 62 & 58 & 57 & 56 & 96 & 96 & 96 & 96 \\
\hline \multicolumn{9}{|l|}{ Income Quintile } \\
\hline 1st Quintile & 21 & 23 & 23 & 22 & 36 & 38 & 40 & 43 \\
\hline 2nd Quintile & 46 & 47 & 44 & 40 & 69 & 71 & 73 & 73 \\
\hline 3rd Quintile & 61 & 56 & 52 & 49 & 85 & 85 & 85 & 85 \\
\hline 4th Quintile & 61 & 59 & 58 & 54 & 93 & 92 & 92 & 92 \\
\hline 5th Quintile & 62 & 59 & 57 & 54 & 96 & 95 & 95 & 95 \\
\hline
\end{tabular}

Note: Projections exclude individuals with family wealth in the top 5 percent of the distribution. Shared lifetime earnings is the average of wage-indexed shared earnings between ages 22 and 62, where shared earnings are computed by assigning each individual half the total earnings of the couple in the years when the individual is married and his or her own earnings in years when nonmarried.

Source: Authors' computations of MINT5 (see text for details). 
Table 5. Mean Family Income Per Person at Age 67 (in thousands, \$2007)

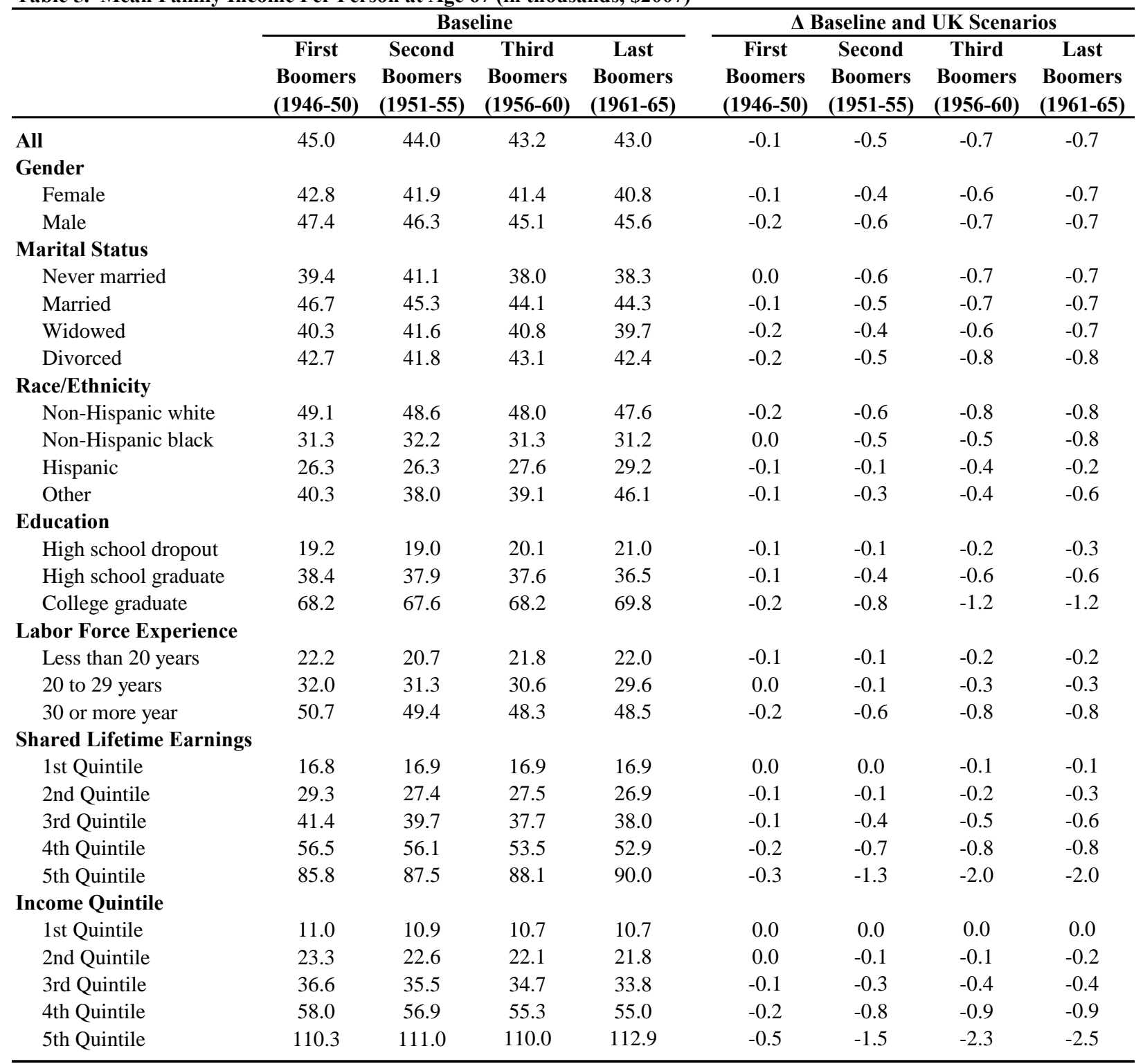

Note: Projections exclude individuals with family wealth in the top 5 percent of the distribution. Shared lifetime earnings is the average of wage-indexed shared earnings between ages 22 and 62, where shared earnings are computed by assigning each individual half the total earnings of the couple in the years when the individual is married and his or her own earnings in years when nonmarried.

Source: Authors' computations of MINT5 (see text for details). 
Table 6. Percent Change in Mean Family Income Per Person at Age 67

Between the Baseline and UK Scenarios (\%)

\begin{tabular}{|c|c|c|c|c|}
\hline & $\begin{array}{c}\text { First } \\
\text { Boomers } \\
(\mathbf{1 9 4 6 - 5 0 )} \\
\end{array}$ & $\begin{array}{c}\text { Second } \\
\text { Boomers } \\
(\mathbf{1 9 5 1 - 5 5 )}\end{array}$ & $\begin{array}{c}\text { Third } \\
\text { Boomers } \\
(\mathbf{1 9 5 6 - 6 0 )}\end{array}$ & $\begin{array}{c}\text { Last } \\
\text { Boomers } \\
(\mathbf{1 9 6 1 - 6 5 )}\end{array}$ \\
\hline All & -0.3 & -1.1 & -1.6 & -1.6 \\
\hline \multicolumn{5}{|l|}{ Gender } \\
\hline Female & -0.3 & -1.0 & -1.5 & -1.7 \\
\hline Male & -0.3 & -1.2 & -1.7 & -1.6 \\
\hline \multicolumn{5}{|l|}{ Marital Status } \\
\hline Never married & 0.0 & -1.5 & -2.0 & -1.8 \\
\hline Married & -0.3 & -1.1 & -1.5 & -1.5 \\
\hline Widowed & -0.4 & -0.9 & -1.4 & -1.8 \\
\hline Divorced & -0.5 & -1.2 & -1.8 & -1.8 \\
\hline \multicolumn{5}{|l|}{ Race/Ethnicity } \\
\hline Non-Hispanic white & -0.3 & -1.1 & -1.6 & -1.7 \\
\hline Non-Hispanic black & -0.1 & -1.6 & -1.5 & -2.6 \\
\hline Hispanic & -0.3 & -0.4 & -1.4 & -0.8 \\
\hline Other & -0.3 & -0.8 & -1.1 & -1.2 \\
\hline \multicolumn{5}{|l|}{ Education } \\
\hline High school dropout & -0.3 & -0.5 & -0.8 & -1.6 \\
\hline High school graduate & -0.3 & -1.1 & -1.5 & -1.6 \\
\hline College graduate & -0.3 & -1.2 & -1.8 & -1.7 \\
\hline \multicolumn{5}{|l|}{ Labor Force Experience } \\
\hline Less than 20 years & -0.3 & -0.4 & -0.7 & -1.0 \\
\hline 20 to 29 years & 0.0 & -0.4 & -1.1 & -0.9 \\
\hline 30 or more year & -0.3 & -1.2 & -1.7 & -1.8 \\
\hline \multicolumn{5}{|l|}{ Shared Lifetime Earnings } \\
\hline 1st Quintile & 0.0 & -0.2 & -0.5 & -0.9 \\
\hline 2nd Quintile & -0.3 & -0.5 & -0.7 & -1.1 \\
\hline 3rd Quintile & -0.3 & -0.9 & -1.4 & -1.6 \\
\hline 4th Quintile & -0.4 & -1.3 & -1.5 & -1.4 \\
\hline 5th Quintile & -0.4 & -1.5 & -2.3 & -2.2 \\
\hline \multicolumn{5}{|l|}{ Income Quintile } \\
\hline 1st Quintile & 0.0 & 0.0 & -0.1 & -0.1 \\
\hline 2nd Quintile & 0.2 & -0.4 & -0.6 & -0.8 \\
\hline 3rd Quintile & -0.3 & -0.7 & -1.2 & -1.2 \\
\hline 4th Quintile & -0.4 & -1.4 & -1.7 & -1.6 \\
\hline 5th Quintile & -0.5 & -1.4 & -2.1 & -2.2 \\
\hline
\end{tabular}

Note: Projections exclude individuals with family wealth in the top 5 percent of the distribution. Shared lifetime earnings is the average of wage-indexed shared earnings between ages 22 and 62, where shared earnings are computed by assigning each individual half the total earnings of the couple in the years when the individual is married and his or her own earnings in years when nonmarried.

Source: Authors' computations of MINT5 (see text for details). 
Table 7. Percent of Individuals Who Win and Lose at Age 67 Between the Baseline and UK Scenarios (\%)

\begin{tabular}{|c|c|c|c|c|c|c|c|c|}
\hline & \multicolumn{4}{|c|}{ Winners } & \multicolumn{4}{|c|}{ Losers } \\
\hline & $\begin{array}{c}\text { First } \\
\text { Boomers } \\
(1946-50) \\
\end{array}$ & $\begin{array}{c}\text { Second } \\
\text { Boomers } \\
(1951-55) \\
\end{array}$ & $\begin{array}{c}\text { Third } \\
\text { Boomers } \\
(1956-60) \\
\end{array}$ & $\begin{array}{c}\text { Last } \\
\text { Boomers } \\
(1961-65) \\
\end{array}$ & $\begin{array}{c}\text { First } \\
\text { Boomers } \\
(1946-50) \\
\end{array}$ & $\begin{array}{c}\text { Second } \\
\text { Boomers } \\
(1951-55) \\
\end{array}$ & $\begin{array}{c}\text { Third } \\
\text { Boomers } \\
(1956-60) \\
\end{array}$ & $\begin{array}{c}\text { Last } \\
\text { Boomers } \\
(1961-65) \\
\end{array}$ \\
\hline All & 7 & 8 & 9 & 11 & 12 & 18 & 22 & 26 \\
\hline \multicolumn{9}{|l|}{ Gender } \\
\hline Female & 6 & 7 & 9 & 10 & 10 & 17 & 21 & 25 \\
\hline Male & 9 & 9 & 10 & 12 & 14 & 20 & 23 & 27 \\
\hline \multicolumn{9}{|l|}{ Marital Status } \\
\hline Never married & 4 & 4 & 6 & 7 & 6 & 14 & 17 & 20 \\
\hline Married & 9 & 9 & 11 & 13 & 13 & 20 & 24 & 28 \\
\hline Widowed & 4 & 5 & 7 & 9 & 8 & 14 & 16 & 22 \\
\hline Divorced & 5 & 5 & 7 & 8 & 9 & 14 & 18 & 24 \\
\hline \multicolumn{9}{|l|}{ Race/Ethnicity } \\
\hline Non-Hispanic white & 8 & 8 & 10 & 11 & 13 & 20 & 24 & 28 \\
\hline Non-Hispanic black & 5 & 6 & 8 & 10 & 10 & 16 & 18 & 22 \\
\hline Hispanic & 5 & 6 & 7 & 9 & 8 & 11 & 17 & 18 \\
\hline Other & 5 & 7 & 9 & 9 & 10 & 14 & 15 & 23 \\
\hline \multicolumn{9}{|l|}{ Education } \\
\hline High school dropout & 3 & 4 & 5 & 6 & 6 & 8 & 11 & 14 \\
\hline High school graduate & 7 & 8 & 9 & 11 & 12 & 18 & 21 & 24 \\
\hline College graduate & 10 & 9 & 11 & 12 & 15 & 22 & 28 & 34 \\
\hline \multicolumn{9}{|l|}{ Labor Force Experience } \\
\hline Less than 20 years & 2 & 2 & 3 & 4 & 3 & 5 & 6 & 9 \\
\hline 20 to 29 years & 4 & 7 & 7 & 9 & 5 & 9 & 14 & 16 \\
\hline 30 or more year & 9 & 9 & 11 & 12 & 14 & 21 & 25 & 30 \\
\hline \multicolumn{9}{|l|}{ Shared Lifetime Earnings } \\
\hline 1st Quintile & 1 & 2 & 4 & 6 & 2 & 4 & 6 & 9 \\
\hline 2nd Quintile & 5 & 7 & 8 & 10 & 8 & 12 & 15 & 21 \\
\hline 3rd Quintile & 8 & 9 & 10 & 12 & 13 & 19 & 23 & 26 \\
\hline 4th Quintile & 10 & 10 & 12 & 13 & 16 & 25 & 28 & 30 \\
\hline 5th Quintile & 13 & 11 & 12 & 13 & 20 & 31 & 37 & 44 \\
\hline \multicolumn{9}{|l|}{ Income Quintile } \\
\hline 1st Quintile & 1 & 2 & 4 & 6 & 2 & 3 & 6 & 8 \\
\hline 2nd Quintile & 5 & 8 & 8 & 10 & 6 & 11 & 15 & 19 \\
\hline 3rd Quintile & 7 & 10 & 10 & 12 & 13 & 19 & 23 & 25 \\
\hline 4th Quintile & 11 & 9 & 12 & 13 & 18 & 26 & 29 & 30 \\
\hline 5th Quintile & 13 & 11 & 12 & 12 & 20 & 32 & 38 & 48 \\
\hline
\end{tabular}

Note: Projections exclude individuals with family wealth in the top 5 percent of the distribution. Shared lifetime earnings is the average of wageindexed shared earnings between ages 22 and 62, where shared earnings are computed by assigning each individual half the total earnings of the couple in the years when the individual is married and his or her own earnings in years when nonmarried. Winners and losers are defined as having at least a $\$ 10$ change in income between the baseline and UK scenario.

Source: Authors' computations of MINT5 (see text for details). 
Table 8. Percent of Individuals Who Win and Lose Five Percent or More of Income at Age 67

Between the Baseline and UK Scenarios (\%)

\begin{tabular}{|c|c|c|c|c|c|c|c|c|}
\hline & \multicolumn{4}{|c|}{ Winners } & \multicolumn{4}{|c|}{ Losers } \\
\hline & $\begin{array}{c}\text { First } \\
\text { Boomers } \\
(\mathbf{1 9 4 6 - 5 0 )}\end{array}$ & $\begin{array}{c}\text { Second } \\
\text { Boomers } \\
(\mathbf{1 9 5 1 - 5 5 )} \\
\end{array}$ & $\begin{array}{c}\text { Third } \\
\text { Boomers } \\
(\mathbf{1 9 5 6 - 6 0 )}\end{array}$ & $\begin{array}{c}\text { Last } \\
\text { Boomers } \\
(\mathbf{1 9 6 1 - 6 5 )}\end{array}$ & $\begin{array}{c}\text { First } \\
\text { Boomers } \\
(\mathbf{1 9 4 6 - 5 0 )} \\
\end{array}$ & $\begin{array}{c}\text { Second } \\
\text { Boomers } \\
(\mathbf{1 9 5 1 - 5 5 )}\end{array}$ & $\begin{array}{c}\text { Third } \\
\text { Boomers } \\
(\mathbf{1 9 5 6 - 6 0 )}\end{array}$ & $\begin{array}{c}\text { Last } \\
\text { Boomers } \\
(\mathbf{1 9 6 1 - 6 5 )}\end{array}$ \\
\hline All & 1 & 1 & 2 & 3 & 3 & 7 & 9 & 10 \\
\hline \multicolumn{9}{|l|}{ Gender } \\
\hline Female & 1 & 1 & 2 & 2 & 3 & 7 & 9 & 11 \\
\hline Male & 1 & 1 & 2 & 3 & 3 & 8 & 10 & 10 \\
\hline \multicolumn{9}{|l|}{ Marital Status } \\
\hline Never married & 1 & 1 & 2 & 3 & 1 & 7 & 8 & 8 \\
\hline Married & 1 & 1 & 2 & 3 & 3 & 8 & 10 & 11 \\
\hline Widowed & 1 & 1 & 1 & 3 & 2 & 6 & 7 & 9 \\
\hline Divorced & 1 & 1 & 2 & 2 & 3 & 6 & 9 & 11 \\
\hline \multicolumn{9}{|l|}{ Race/Ethnicity } \\
\hline Non-Hispanic white & 1 & 1 & 2 & 3 & 3 & 8 & 10 & 11 \\
\hline Non-Hispanic black & 1 & 1 & 2 & 3 & 3 & 7 & 10 & 12 \\
\hline Hispanic & 1 & 1 & 2 & 2 & 3 & 3 & 7 & 7 \\
\hline Other & 0 & 1 & 2 & 2 & 1 & 5 & 5 & 7 \\
\hline \multicolumn{9}{|l|}{ Education } \\
\hline High school dropout & 0 & 1 & 1 & 1 & 1 & 2 & 4 & 6 \\
\hline High school graduate & 1 & 1 & 2 & 3 & 3 & 7 & 10 & 11 \\
\hline College graduate & 1 & 1 & 2 & 3 & 4 & 8 & 10 & 12 \\
\hline \multicolumn{9}{|l|}{ Labor Force Experience } \\
\hline Less than 20 years & 0 & 0 & 1 & 1 & 1 & 1 & 2 & 4 \\
\hline 20 to 29 years & 1 & 1 & 1 & 2 & 2 & 3 & 6 & 6 \\
\hline 30 or more year & 1 & 1 & 2 & 3 & 4 & 9 & 11 & 12 \\
\hline \multicolumn{9}{|c|}{ Shared Lifetime Earnings } \\
\hline 1st Quintile & 0 & 0 & 1 & 1 & 1 & 1 & 2 & 3 \\
\hline 2nd Quintile & 1 & 1 & 2 & 3 & 2 & 4 & 6 & 8 \\
\hline 3rd Quintile & 1 & 1 & 2 & 3 & 3 & 8 & 10 & 12 \\
\hline 4th Quintile & 1 & 1 & 3 & 4 & 4 & 11 & 13 & 13 \\
\hline 5th Quintile & 2 & 2 & 2 & 3 & 5 & 12 & 15 & 16 \\
\hline \multicolumn{9}{|l|}{ Income Quintile } \\
\hline 1st Quintile & 0 & 1 & 1 & 2 & 1 & 1 & 2 & 3 \\
\hline 2nd Quintile & 1 & 1 & 2 & 3 & 2 & 4 & 7 & 9 \\
\hline 3rd Quintile & 1 & 1 & 2 & 3 & 4 & 8 & 11 & 12 \\
\hline 4th Quintile & 1 & 1 & 2 & 3 & 4 & 12 & 15 & 14 \\
\hline 5th Quintile & 1 & 1 & 1 & 2 & 5 & 10 & 12 & 15 \\
\hline
\end{tabular}

Note: Sample includes individuals with a change of $\$ 10$ in per person family income at age 67 between the baseline and UK scenarios.

Projections exclude individuals with family wealth in the top 5 percent of the distribution. Shared lifetime earnings is the average of wageindexed shared earnings between ages 22 and 62, where shared earnings are computed by assigning each individual half the total earnings of the couple in the years when the individual is married and his or her own earnings in years when nonmarried. Winners and losers are defined as having a five percent or more change in income between the baseline and UK scenario.

Source: Authors' computations of MINT5 (see text for details). 
Table 9. Change in Mean Family Income Per Person at Age 67 for Winners and Losers Between the Baseline and UK Scenarios (in thousands, \$2007)

\begin{tabular}{|c|c|c|c|c|c|c|c|c|}
\hline & \multicolumn{4}{|c|}{ Winners } & \multicolumn{4}{|c|}{ Losers } \\
\hline & $\begin{array}{c}\text { First } \\
\text { Boomers } \\
(\mathbf{1 9 4 6 - 5 0 )} \\
\end{array}$ & $\begin{array}{c}\text { Second } \\
\text { Boomers } \\
(\mathbf{1 9 5 1 - 5 5 )} \\
\end{array}$ & $\begin{array}{c}\text { Third } \\
\text { Boomers } \\
(\mathbf{1 9 5 6 - 6 0 )} \\
\end{array}$ & $\begin{array}{c}\text { Last } \\
\text { Boomers } \\
(\mathbf{1 9 6 1 - 6 5 )} \\
\end{array}$ & $\begin{array}{c}\text { First } \\
\text { Boomers } \\
(\mathbf{1 9 4 6 - 5 0 )} \\
\end{array}$ & $\begin{array}{c}\text { Second } \\
\text { Boomers } \\
(\mathbf{1 9 5 1 - 5 5 )} \\
\end{array}$ & $\begin{array}{c}\text { Third } \\
\text { Boomers } \\
(1956-60) \\
\end{array}$ & $\begin{array}{c}\text { Last } \\
\text { Boomers } \\
(\mathbf{1 9 6 1 - 6 5 )} \\
\end{array}$ \\
\hline All & 2.1 & 1.8 & 1.8 & 2.8 & -2.6 & -3.7 & -4.2 & -4.2 \\
\hline \multicolumn{9}{|l|}{ Gender } \\
\hline Female & 2.0 & 2.1 & 1.7 & 3.0 & -2.6 & -3.6 & -4.0 & -4.2 \\
\hline Male & 2.1 & 1.5 & 1.8 & 2.5 & -2.5 & -3.9 & -4.3 & -4.3 \\
\hline \multicolumn{9}{|l|}{ Marital Status } \\
\hline Never married & 3.8 & 1.4 & 2.7 & 4.7 & -2.5 & -5.3 & -6.2 & -6.1 \\
\hline Married & 2.1 & 1.5 & 1.5 & 2.3 & -2.4 & -3.3 & -3.5 & -3.8 \\
\hline Widowed & 1.3 & 4.8 & 1.8 & 4.1 & -3.0 & -4.7 & -4.8 & -5.5 \\
\hline Divorced & 1.7 & 1.9 & 2.9 & 3.6 & -3.3 & -4.7 & -5.9 & -5.0 \\
\hline \multicolumn{9}{|l|}{ Race/Ethnicity } \\
\hline Non-Hispanic white & 2.1 & 1.9 & 1.7 & 3.0 & -2.7 & -3.8 & -4.3 & -4.5 \\
\hline Non-Hispanic black & 3.2 & 1.5 & 3.3 & 1.6 & -1.8 & -3.9 & -4.2 & -4.6 \\
\hline Hispanic & 1.6 & 1.1 & 1.2 & 2.7 & -2.2 & -1.6 & -2.9 & -2.6 \\
\hline Other & 0.8 & 2.0 & 2.0 & 1.7 & -1.6 & -4.2 & -4.3 & -3.2 \\
\hline \multicolumn{9}{|l|}{ Education } \\
\hline High school dropout & 1.0 & 1.3 & 1.1 & 1.0 & -1.5 & -1.7 & -2.1 & -2.8 \\
\hline High school graduate & 1.4 & 1.6 & 1.3 & 2.1 & -1.9 & -3.0 & -3.3 & -3.4 \\
\hline College graduate & 3.1 & 2.2 & 2.9 & 4.7 & -3.8 & -5.6 & -6.7 & -6.1 \\
\hline \multicolumn{9}{|l|}{ Labor Force Experience } \\
\hline Less than 20 years & 0.9 & 1.3 & 1.3 & 1.1 & -3.1 & -2.5 & -3.3 & -3.3 \\
\hline 20 to 29 years & 2.5 & 1.4 & 0.8 & 1.4 & -2.2 & -2.6 & -3.1 & -2.6 \\
\hline 30 or more year & 2.1 & 1.8 & 1.9 & 3.0 & -2.6 & -3.8 & -4.3 & -4.4 \\
\hline \multicolumn{9}{|c|}{ Shared Lifetime Earnings } \\
\hline 1st Quintile & 1.9 & 0.5 & 0.5 & 0.7 & -1.5 & -1.2 & -1.6 & -2.2 \\
\hline 2nd Quintile & 0.8 & 0.6 & 1.2 & 1.3 & -1.5 & -1.6 & -1.8 & -2.0 \\
\hline 3rd Quintile & 1.6 & 1.1 & 1.1 & 1.4 & -1.8 & -2.5 & -2.8 & -3.1 \\
\hline 4th Quintile & 1.8 & 2.2 & 2.5 & 3.1 & -2.5 & -3.8 & -4.0 & -4.0 \\
\hline 5th Quintile & 3.1 & 3.1 & 2.7 & 6.4 & -3.9 & -6.1 & -7.5 & -7.6 \\
\hline \multicolumn{9}{|l|}{ Income Quintile } \\
\hline 1st Quintile & 0.9 & 0.7 & 0.7 & 0.8 & -0.6 & -0.7 & -0.6 & -0.7 \\
\hline 2nd Quintile & 2.1 & 0.6 & 1.1 & 1.4 & -1.0 & -1.2 & -1.6 & -1.6 \\
\hline 3rd Quintile & 1.3 & 1.7 & 1.4 & 2.2 & -1.5 & -2.2 & -2.5 & -2.7 \\
\hline 4th Quintile & 1.7 & 1.7 & 2.3 & 3.1 & -2.2 & -3.7 & -4.2 & -4.4 \\
\hline 5th Quintile & 3.1 & 3.3 & 2.5 & 5.8 & -4.6 & -6.8 & -8.2 & -8.0 \\
\hline
\end{tabular}

Note: Projections exclude individuals with family wealth in the top 5 percent of the distribution. Shared lifetime earnings is the average of wageindexed shared earnings between ages 22 and 62, where shared earnings are computed by assigning each individual half the total earnings of the couple in the years when the individual is married and his or her own earnings in years when nonmarried. Winners and losers are defined as having at least a $\$ 10$ change in income between the baseline and UK scenario.

Source: Authors' computations of MINT5 (see text for details). 
Table 10. Mean Family Income Per Person at Age 67 for Winners and Losers, by Source (in thousands, \$2007)

\begin{tabular}{|c|c|c|c|c|c|c|c|c|}
\hline & \multicolumn{4}{|c|}{ Baseline } & \multicolumn{4}{|c|}{$\Delta$ Baseline and UK Scenarios } \\
\hline & $\begin{array}{c}\text { First } \\
\text { Boomers } \\
(1946-50) \\
\end{array}$ & $\begin{array}{c}\text { Second } \\
\text { Boomers } \\
(\mathbf{1 9 5 1 - 5 5 )} \\
\end{array}$ & $\begin{array}{c}\text { Third } \\
\text { Boomers } \\
(\mathbf{1 9 5 6 - 6 0 )} \\
\end{array}$ & $\begin{array}{c}\text { Last } \\
\text { Boomers } \\
(\mathbf{1 9 6 1 - 6 5 )} \\
\end{array}$ & $\begin{array}{c}\text { First } \\
\text { Boomers } \\
(1946-50) \\
\end{array}$ & $\begin{array}{c}\text { Second } \\
\text { Boomers } \\
(1951-55) \\
\end{array}$ & $\begin{array}{c}\text { Third } \\
\text { Boomers } \\
(\mathbf{1 9 5 6 - 6 0 )} \\
\end{array}$ & $\begin{array}{c}\text { Last } \\
\text { Boomers } \\
(\mathbf{1 9 6 1 - 6 5 )} \\
\end{array}$ \\
\hline \multicolumn{9}{|l|}{ Winners } \\
\hline Income from Assets & 8.6 & 7.9 & 7.9 & 7.3 & 0.0 & 0.0 & -0.1 & -0.1 \\
\hline Earnings & 19.4 & 14.1 & 11.8 & 13.3 & 0.5 & 0.5 & 0.6 & 1.3 \\
\hline SSI Benefits & 0.0 & 0.0 & 0.0 & 0.0 & 0.0 & 0.0 & 0.0 & 0.0 \\
\hline Imputed Rental Income & 3.7 & 3.5 & 3.2 & 2.9 & 0.0 & 0.0 & 0.0 & 0.0 \\
\hline Social Security Benefits & 14.4 & 14.4 & 13.9 & 13.7 & 0.0 & 0.0 & 0.1 & 0.1 \\
\hline DB Pension Benefits & 8.3 & 4.9 & 4.1 & 2.9 & 1.1 & 0.5 & -0.1 & -0.6 \\
\hline Retirement Accounts & 9.4 & 9.1 & 9.7 & 9.5 & 0.4 & 0.8 & 1.3 & 2.1 \\
\hline Total Income & 63.9 & 53.8 & 50.6 & 49.5 & 2.1 & 1.8 & 1.8 & 2.8 \\
\hline \multicolumn{9}{|l|}{ Losers } \\
\hline Income from Assets & 7.6 & 8.0 & 8.4 & 9.4 & 0.0 & 0.0 & 0.0 & -0.1 \\
\hline Earnings & 14.8 & 11.0 & 10.7 & 11.3 & 0.0 & -0.1 & -0.1 & -0.1 \\
\hline SSI Benefits & 0.0 & 0.0 & 0.0 & 0.0 & 0.0 & 0.0 & 0.0 & 0.0 \\
\hline Imputed Rental Income & 3.7 & 3.5 & 3.4 & 3.6 & 0.0 & 0.0 & 0.0 & 0.0 \\
\hline Social Security Benefits & 15.4 & 15.8 & 15.3 & 15.3 & 0.0 & 0.0 & 0.0 & 0.0 \\
\hline DB Pension Benefits & 11.6 & 10.2 & 8.4 & 7.2 & -2.6 & -3.8 & -4.3 & -4.3 \\
\hline Retirement Accounts & 11.3 & 11.8 & 12.1 & 12.1 & 0.1 & 0.2 & 0.3 & 0.2 \\
\hline Total Income & 64.4 & 60.3 & 58.3 & 58.9 & -2.6 & -3.7 & -4.2 & -4.2 \\
\hline
\end{tabular}

Note: Projections exclude individuals with family wealth in the top 5 percent of the distribution. Winners and losers are defined as having at least a $\$ 10$ change in income between the baseline and UK scenario.

Source: Authors' computations of MINT5 (see text for details). 


\section{Appendix A}

MINT begins with pooled 1990 to 1996 SIPP data. The 1990 to 1993 panels include individuals born from 1926 to 1965 . The 1996 panel includes individuals born from 1926 to 1972. MINT also creates individuals born from 1973 to 2018 and immigrants that arrive after 1996 using a cloning process.

The SIPP data include numerous demographic characteristics, including marriage history, migration history, health and disability status, and the number and relationships of people in the household. The SIPP also contains detailed income and wealth characteristics such as home equity, financial assets, pension characteristics and assets, Social Security and Supplemental Security Income (SSI) benefits, and income from wages and salaries, self-employment, and pensions.

MINT uses earnings from Social Security administrative data for the years 1951 through 2004 for individuals with a valid Social Security number, matched to the 1990-1993 and 1996 SIPP. MINT statistically imputes an earnings record for all non-matched respondents by selecting a similar respondent with a valid match. Matching variables in this imputation include age, sex, education, self-reported SIPP earnings, immigration age, and deferred contribution (DC) pension status.

MINT then projects annual earnings and disability onset through age 67 using a "nearest neighbor” matching procedure. MINT starts with a person’s own Social Security Administration (SSA) recorded earnings from 1951 to 2004. The nearest neighbor procedure statistically assigns to each "recipient” worker the next five years of earnings and Social Security Disability Insurance (DI) entitlement status, based on the earnings and DI status of a "donor” MINT 
observation born five years earlier with similar characteristics. The splicing of five-year blocks of earnings from donors to recipients continues until earnings projections reach age 67. A number of criteria are used to match recipients with donors in the same age interval. These criteria include gender, minority group status, education level, DI entitlement status, self employment status, average earnings over the prior five-year period, presence of earnings in the 4th and 5th years of the prior five-year period, and age-gender group quintile of average prematch period earnings. An advantage of this approach is that it preserves the observed heterogeneity in age-earnings profiles for earlier birth cohorts in projecting earnings of later cohorts.

In a subsequent process, for all individuals who never become DI recipients, MINT projects earnings, retirement, and benefit take-up from age 55 until death. These earnings replace the earnings generated from the splicing method from age 55 until retirement. This post-process allows the model to project behavioral changes in earnings, retirement, and benefit take-up in response to policy changes. MINT then calculates Social Security benefits based on earnings histories and DI entitlement status of workers, marital histories, and earnings histories of current and former spouses.

Social Security benefits in MINT are calculated using a detailed Social Security benefit calculator. MINT's calculated benefits use earnings from the SER and should generate actual benefits from the MBR. Calculated and actual benefits will not match in cases when the benefits are based on a former spouse. MINT selects former spouses (who bring with them their earnings histories), and to ensure consistency in benefits with earnings and spouse characteristics, MINT uses calculated Social Security benefits. MINT's benefits are based on full-year values even in 
the first year of benefit take-up. The actuarial reduction factor accounts for the age in months at take-up, but there is no adjustment in annual benefits for part-year receipt.

MINT projects pension coverage and benefits starting with the self-reported pension coverage information in the SIPP. MINT then links individuals to pension plans and simulates new pension plans along with job changes. Pension accruals depend on the characteristics of individuals’ specific pension plan parameters and simulated job tenure. MINT also projects wealth from retirement accounts (i.e. DC, IRA, and Keogh plans) to the retirement date based on initial account balances and projected new contributions and investment earnings.

MINT also projects housing equity and non-pension, non-housing wealth (i.e. vehicles, other real estate, farm and business equity, stock, mutual fund, and bond values, checking, saving, money market, and certificate of deposit account balances, less unsecured debt). These projections are based on random-effects models of wealth accumulation estimated from the Panel Survey of Income Dynamics (PSID), HRS, and the SIPP. Explanatory variables include age, recent earnings and present value of lifetime earnings, number of years with earnings above the Social Security taxable maximum, marital status, gender, number and age of children, education, race, health and disability status, pension coverage, self-employment status, and last year of life.

MINT also projects living arrangements, SSI income, and income of non-spouse coresidents from age 62 until death. Living arrangements depend on marital status, age, gender, race, ethnicity, nativity, number of children ever born, education, income and assets of the individual, and date of death. For those projected to co-reside, MINT uses a "nearest neighbor" match to assign the income and characteristics of the other family members from a donor file of co-resident families from pooled 1990 to 1993 SIPP panels. After all incomes and assets are 
calculated, MINT calculates SSI eligibility and projects participation and benefits for eligible participants.

Finally, MINT calculates annual state and federal income taxes from federal and state tax calculators and additional data from a statistical match with an enhanced Statistics of Income (SOI) file. The statistical match uses a minimum distance function. The key match variables are filing status, age of family head, wage and salary earnings, self-employment earnings, pension income, Social Security benefits, home equity, and financial assets. The enhanced SOI is used as the data source for interest, dividends, rental income, and itemized deductions; these variables are needed for calculation of income tax liabilities.

The enhanced SOI file used with MINT is based on the 2001 SOI statistically matched to the 1996 SIPP to add home equity, financial assets, and age. This match uses a minimum distance function that includes filing status, state, number of exemptions, wage and salary income, self-employment income, Social Security income, pension income, IRA distributions, interest, dividends, rental income, alimony, and unemployment compensation.

This report calculates asset income based on the annuity that families could purchase from 80 percent of financial assets. MINT uses this annuity income to calculate retirement income; not the SOI imputed interest, dividends, and rental income. MINT uses the potential annuity instead of capital income from assets as an income measure to treat families with DC pensions in a comparable fashion as families with DB pensions. The potential annuity amount will exceed the return on capital—interest, dividends, and rental income—because the annuity includes repayment of principal in addition to capital income. This places the measured income from DC accounts on an equivalent scale with reported DB pension income, which includes both the return on assets and repayment of principal. 
MINT projects income and demographic transitions annually from the SIPP interview year until the earlier of emigration, institutionalization, death, or 2099. The earnings and benefit status come directly from the administrative data through 2004. Per capita income and assets depend on economic and demographic (marriage, divorce, and death) changes over the period. 
Table B1. Percent Change in Mean Per Person Family Income at Age 67 for Winners and Losers Between the Baseline and UK Scenarios (\%)

\begin{tabular}{|c|c|c|c|c|c|c|c|c|}
\hline & \multicolumn{4}{|c|}{ Winners } & \multicolumn{4}{|c|}{ Losers } \\
\hline & $\begin{array}{c}\text { First } \\
\text { Boomers } \\
(\mathbf{1 9 4 6 - 5 0 )} \\
\end{array}$ & $\begin{array}{c}\text { Second } \\
\text { Boomers } \\
(\mathbf{1 9 5 1 - 5 5 )} \\
\end{array}$ & $\begin{array}{c}\text { Third } \\
\text { Boomers } \\
(\mathbf{1 9 5 6 - 6 0 )} \\
\end{array}$ & $\begin{array}{c}\text { Last } \\
\text { Boomers } \\
(\mathbf{1 9 6 1 - 6 5 )} \\
\end{array}$ & $\begin{array}{c}\text { First } \\
\text { Boomers } \\
(\mathbf{1 9 4 6 - 5 0 )} \\
\end{array}$ & $\begin{array}{c}\text { Second } \\
\text { Boomers } \\
(\mathbf{1 9 5 1 - 5 5 )}\end{array}$ & $\begin{array}{c}\text { Third } \\
\text { Boomers } \\
(1956-60) \\
\end{array}$ & $\begin{array}{c}\text { Last } \\
\text { Boomers } \\
(\mathbf{1 9 6 1 - 6 5 )} \\
\end{array}$ \\
\hline All & 3.2 & 3.3 & 3.5 & 5.6 & -4.0 & -6.1 & -7.1 & -7.2 \\
\hline \multicolumn{9}{|l|}{ Gender } \\
\hline Female & 3.3 & 4.1 & 3.5 & 6.3 & -4.1 & -6.2 & -7.0 & -7.6 \\
\hline Male & 3.1 & 2.7 & 3.5 & 5.0 & -3.9 & -6.1 & -7.2 & -6.9 \\
\hline \multicolumn{9}{|l|}{ Marital Status } \\
\hline Never married & 4.0 & 2.8 & 5.1 & 8.2 & -4.4 & -7.7 & -9.6 & -8.9 \\
\hline Married & 3.3 & 2.8 & 2.9 & 4.8 & -3.8 & -5.7 & -6.4 & -6.7 \\
\hline Widowed & 1.8 & 8.6 & 3.2 & 8.3 & -4.4 & -7.3 & -7.7 & -9.5 \\
\hline Divorced & 2.9 & 3.9 & 6.2 & 7.2 & -4.9 & -7.0 & -8.9 & -7.6 \\
\hline \multicolumn{9}{|l|}{ Race/Ethnicity } \\
\hline Non-Hispanic white & 3.1 & 3.2 & 3.1 & 5.7 & -4.0 & -6.1 & -7.0 & -7.3 \\
\hline Non-Hispanic black & 5.9 & 4.0 & 8.5 & 5.1 & -4.2 & -7.8 & -9.4 & -10.2 \\
\hline Hispanic & 3.4 & 3.1 & 3.1 & 6.3 & -5.0 & -3.9 & -7.3 & -6.4 \\
\hline Other & 1.5 & 4.1 & 4.0 & 2.9 & -2.5 & -6.1 & -6.6 & -4.4 \\
\hline \multicolumn{9}{|l|}{ Education } \\
\hline High school dropout & 3.0 & 4.6 & 3.6 & 4.4 & -3.8 & -5.2 & -6.8 & -8.8 \\
\hline High school graduate & 2.7 & 3.5 & 3.1 & 5.2 & -3.6 & -5.8 & -6.7 & -7.5 \\
\hline College graduate & 3.7 & 3.0 & 4.0 & 6.1 & -4.4 & -6.6 & -7.8 & -6.8 \\
\hline \multicolumn{9}{|l|}{ Labor Force Experience } \\
\hline Less than 20 years & 1.8 & 2.8 & 3.4 & 4.0 & -5.1 & -5.7 & -8.8 & -8.5 \\
\hline 20 to 29 years & 4.4 & 3.4 & 2.1 & 4.3 & -4.3 & -5.2 & -7.0 & -6.9 \\
\hline 30 or more year & 3.2 & 3.3 & 3.6 & 5.7 & -4.0 & -6.2 & -7.1 & -7.2 \\
\hline \multicolumn{9}{|c|}{ Shared Lifetime Earnings } \\
\hline 1st Quintile & 7.7 & 2.1 & 2.5 & 3.3 & -5.5 & -5.5 & -7.6 & -10.1 \\
\hline 2nd Quintile & 2.4 & 2.3 & 4.2 & 4.6 & -4.1 & -4.8 & -5.8 & -6.9 \\
\hline 3rd Quintile & 3.4 & 2.8 & 2.6 & 3.7 & -3.9 & -5.8 & -6.9 & -7.2 \\
\hline 4th Quintile & 2.9 & 3.8 & 4.5 & 5.5 & -3.9 & -6.3 & -6.8 & -6.9 \\
\hline 5th Quintile & 3.4 & 3.5 & 3.1 & 7.0 & -4.0 & -6.4 & -7.7 & -7.3 \\
\hline \multicolumn{9}{|l|}{ Income Quintile } \\
\hline 1st Quintile & 6.4 & 5.9 & 5.8 & 6.8 & -4.6 & -5.3 & -5.0 & -6.0 \\
\hline 2nd Quintile & 8.7 & 2.5 & 5.0 & 6.4 & -4.3 & -5.2 & -7.0 & -7.2 \\
\hline 3rd Quintile & 3.5 & 4.8 & 4.0 & 6.6 & -4.2 & -6.1 & -7.0 & -8.1 \\
\hline 4th Quintile & 2.9 & 3.1 & 4.3 & 5.7 & -3.8 & -6.6 & -7.5 & -7.9 \\
\hline 5th Quintile & 2.8 & 3.0 & 2.4 & 4.9 & -4.0 & -6.0 & -7.0 & -6.8 \\
\hline
\end{tabular}

Note: Projections exclude individuals with family wealth in the top 5 percent of the distribution. Shared lifetime earnings is the average of wageindexed shared earnings between ages 22 and 62, where shared earnings are computed by assigning each individual half the total earnings of the couple in the years when the individual is married and his or her own earnings in years when nonmarried. Winners and losers are defined as having at least a $\$ 10$ change in income between the baseline and UK scenario.

Source: Authors' computations of MINT5 (see text for details). 
Table B2. Percent of Individuals Who Win, Mean Family Income Per Person (thousands of \$2007), and Percent Change in Family Income at Age 67 for Winners, by Source and Percent Change in Family Income

\begin{tabular}{|c|c|c|c|c|c|c|c|c|}
\hline \multirow[b]{2}{*}{$\begin{array}{l}\text { Percent Change In Family } \\
\text { Income }\end{array}$} & \multicolumn{4}{|c|}{ Baseline } & \multicolumn{4}{|c|}{$\Delta$ Baseline and UK Scenarios } \\
\hline & $\begin{array}{r}\text { First } \\
\text { Boomers } \\
(1946-50) \\
\end{array}$ & $\begin{array}{r}\text { Second } \\
\text { Boomers } \\
(1951-55) \\
\end{array}$ & $\begin{array}{r}\text { Third } \\
\text { Boomers } \\
(1956-60) \\
\end{array}$ & $\begin{array}{r}\text { Last } \\
\text { Boomers } \\
(1961-65) \\
\end{array}$ & $\begin{array}{r}\text { First } \\
\text { Boomers } \\
(1946-50) \\
\end{array}$ & $\begin{array}{r}\text { Second } \\
\text { Boomers } \\
(\mathbf{1 9 5 1 - 5 5 )} \\
\end{array}$ & $\begin{array}{r}\text { Third } \\
\text { Boomers } \\
(1956-60) \\
\end{array}$ & $\begin{array}{r}\text { Last } \\
\text { Boomers } \\
(1961-65) \\
\end{array}$ \\
\hline \multicolumn{9}{|l|}{$<2 \%$} \\
\hline Percent of Individuals & $5 \%$ & $5 \%$ & $6 \%$ & $5 \%$ & & & & \\
\hline Income from Assets & $\$ 9.2$ & $\$ 8.9$ & $\$ 9.1$ & $\$ 8.2$ & $\$ 0.0$ & $\$ 0.0$ & $-\$ 0.1$ & $-\$ 0.1$ \\
\hline Earnings & 22.5 & 16.1 & 14.6 & 16.5 & 0.0 & 0.0 & 0.0 & 0.0 \\
\hline SSI Benefits & 0.0 & 0.0 & 0.0 & 0.0 & 0.0 & 0.0 & 0.0 & 0.0 \\
\hline Imputed Rental Income & 3.9 & 3.6 & 3.5 & 3.2 & 0.0 & 0.0 & 0.0 & 0.0 \\
\hline Social Security Benefits & 14.3 & 14.1 & 13.7 & 13.4 & 0.0 & 0.0 & 0.0 & 0.0 \\
\hline DB Pension Benefits & 7.2 & 4.3 & 3.7 & 2.2 & 0.0 & 0.0 & -0.2 & -0.3 \\
\hline Retirement Accounts & 10.1 & 9.7 & 10.7 & 10.5 & 0.4 & 0.4 & 0.6 & 0.8 \\
\hline Total Income & $\$ 67.2$ & 56.7 & 55.3 & 54.0 & 0.4 & 0.4 & 0.4 & 0.4 \\
\hline \multicolumn{9}{|l|}{$2 \%-<5 \%$} \\
\hline Percent of Individuals & $1 \%$ & $1 \%$ & $2 \%$ & $3 \%$ & & & & \\
\hline Income from Assets & $\$ 8.7$ & $\$ 5.3$ & $\$ 6.1$ & $\$ 7.0$ & $\$ 0.0$ & $-\$ 0.1$ & $-\$ 0.1$ & $-\$ 0.2$ \\
\hline Earnings & 11.7 & 9.9 & 8.6 & 12.6 & 0.0 & 0.1 & 0.0 & 0.1 \\
\hline SSI Benefits & 0.0 & 0.0 & 0.0 & 0.0 & 0.0 & 0.0 & 0.0 & 0.0 \\
\hline Imputed Rental Income & 3.2 & 3.5 & 2.7 & 2.6 & 0.0 & 0.0 & 0.0 & 0.0 \\
\hline Social Security Benefits & 14.5 & 14.7 & 14.2 & 13.6 & 0.0 & 0.0 & 0.0 & 0.0 \\
\hline DB Pension Benefits & 11.0 & 5.4 & 4.8 & 2.8 & 1.1 & 0.2 & -0.1 & -0.4 \\
\hline Retirement Accounts & 6.9 & 7.8 & 9.0 & 10.0 & 0.7 & 1.2 & 1.6 & 2.1 \\
\hline Total Income & 56.0 & 46.6 & 45.3 & 48.6 & 1.8 & 1.5 & 1.4 & 1.6 \\
\hline \multicolumn{9}{|l|}{$>=5 \%$} \\
\hline Percent of Individuals & $1 \%$ & $1 \%$ & $2 \%$ & $3 \%$ & & & & \\
\hline Income from Assets & $\$ 5.3$ & $\$ 5.8$ & $\$ 6.3$ & $\$ 6.0$ & $\$ 0.0$ & $\$ 0.0$ & $\$ 0.0$ & $\$ 0.0$ \\
\hline Earnings & 11.5 & 9.4 & 6.7 & 7.3 & 3.6 & 3.7 & 3.4 & 5.0 \\
\hline SSI Benefits & 0.0 & 0.0 & 0.0 & 0.0 & 0.0 & 0.0 & 0.0 & 0.0 \\
\hline Imputed Rental Income & 3.5 & 3.0 & 2.8 & 2.7 & 0.0 & 0.0 & 0.0 & 0.0 \\
\hline Social Security Benefits & 14.8 & 15.3 & 14.4 & 14.2 & 0.2 & 0.3 & 0.4 & 0.3 \\
\hline DB Pension Benefits & 11.7 & 7.1 & 4.7 & 4.3 & 6.4 & 3.5 & 0.0 & -1.4 \\
\hline Retirement Accounts & 8.4 & 7.8 & 7.3 & 6.9 & 0.6 & 2.1 & 3.0 & 4.6 \\
\hline Total Income & 55.2 & 48.4 & 42.1 & 41.5 & 10.7 & 9.6 & 6.8 & 8.6 \\
\hline
\end{tabular}

Note: Projections exclude individuals with family wealth in the top 5 percent of the distribution. Winners are defined as having at least a $\$ 10$ increase in income between the baseline and UK scenario.

Source: Authors' computations of MINT5 (see text for details). 
Table B3. Percent of Individuals Who Lose, Mean Family Income Per Person (thousands of \$2007), and Percent Change in Family Income at Age 67 for Losers, by Source and Percent Change in Family Income

\begin{tabular}{|c|c|c|c|c|c|c|c|c|}
\hline \multirow[b]{2}{*}{$\begin{array}{l}\text { Percent Change In Family } \\
\text { Income }\end{array}$} & \multicolumn{4}{|c|}{ Baseline } & \multicolumn{4}{|c|}{$\Delta$ Baseline and UK Scenarios } \\
\hline & $\begin{array}{r}\text { First } \\
\text { Boomers } \\
(1946-50) \\
\end{array}$ & $\begin{array}{r}\text { Second } \\
\text { Boomers } \\
(1951-55) \\
\end{array}$ & $\begin{array}{r}\text { Third } \\
\text { Boomers } \\
(1956-60) \\
\end{array}$ & $\begin{array}{r}\text { Last } \\
\text { Boomers } \\
(1961-65) \\
\end{array}$ & $\begin{array}{r}\text { First } \\
\text { Boomers } \\
(\mathbf{1 9 4 6 - 5 0 )} \\
\end{array}$ & $\begin{array}{r}\text { Second } \\
\text { Boomers } \\
(1951-55) \\
\end{array}$ & $\begin{array}{r}\text { Third } \\
\text { Boomers } \\
(1956-60) \\
\end{array}$ & $\begin{array}{r}\text { Last } \\
\text { Boomers } \\
(1961-65) \\
\end{array}$ \\
\hline \multicolumn{9}{|l|}{$<2 \%$} \\
\hline Percent of Individuals & $5 \%$ & $7 \%$ & $8 \%$ & $11 \%$ & & & & \\
\hline Income from Assets & $\$ 9.4$ & $\$ 9.8$ & $\$ 11.4$ & $\$ 13.4$ & $\$ 0.0$ & $\$ 0.0$ & $\$ 0.0$ & $\$ 0.0$ \\
\hline Earnings & 17.9 & 14.8 & 15.1 & 17.1 & 0.0 & 0.0 & 0.0 & 0.0 \\
\hline SSI Benefits & 0.0 & 0.0 & 0.0 & 0.0 & 0.0 & 0.0 & 0.0 & 0.0 \\
\hline Imputed Rental Income & 4.0 & 3.7 & 4.0 & 4.4 & 0.0 & 0.0 & 0.0 & 0.0 \\
\hline Social Security Benefits & 14.9 & 14.9 & 14.7 & 15.6 & 0.0 & 0.0 & 0.0 & 0.0 \\
\hline DB Pension Benefits & 6.0 & 4.7 & 3.0 & 3.1 & -0.4 & -0.5 & -0.5 & -0.5 \\
\hline Retirement Accounts & 13.8 & 12.9 & 12.1 & 12.9 & -0.1 & 0.0 & 0.1 & 0.2 \\
\hline Total Income & 66.0 & 60.8 & 60.3 & 66.5 & -0.6 & -0.5 & -0.4 & -0.3 \\
\hline \multicolumn{9}{|l|}{$2 \%-<5 \%$} \\
\hline Percent of Individuals & $4 \%$ & $4 \%$ & $4 \%$ & $4 \%$ & & & & \\
\hline Income from Assets & $\$ 7.0$ & $\$ 8.0$ & $\$ 7.8$ & $\$ 7.9$ & $\$ 0.0$ & $\$ 0.0$ & $\$ 0.0$ & $\$ 0.0$ \\
\hline Earnings & 12.2 & 9.6 & 8.7 & 10.0 & 0.0 & 0.0 & 0.0 & 0.0 \\
\hline SSI Benefits & 0.0 & 0.0 & 0.0 & 0.0 & 0.0 & 0.0 & 0.0 & 0.0 \\
\hline Imputed Rental Income & 3.8 & 3.5 & 3.3 & 2.7 & 0.0 & 0.0 & 0.0 & 0.0 \\
\hline Social Security Benefits & 15.9 & 15.9 & 15.3 & 14.3 & 0.0 & 0.0 & 0.0 & 0.0 \\
\hline DB Pension Benefits & 12.5 & 8.0 & 5.4 & 4.2 & -2.1 & -1.8 & -1.9 & -1.9 \\
\hline Retirement Accounts & 10.7 & 12.3 & 12.9 & 11.2 & 0.1 & -0.1 & 0.1 & 0.2 \\
\hline Total Income & 62.1 & 57.3 & 53.4 & 50.2 & -2.0 & -1.9 & -1.8 & -1.7 \\
\hline \multicolumn{9}{|l|}{$>=5 \%$} \\
\hline Percent of Individuals & $3 \%$ & $7 \%$ & $9 \%$ & $10 \%$ & & & & \\
\hline Income from Assets & $\$ 5.5$ & $\$ 6.7$ & $\$ 6.5$ & $\$ 6.5$ & $\$ 0.0$ & $-\$ 0.1$ & $-\$ 0.1$ & $-\$ 0.1$ \\
\hline Earnings & 13.1 & 8.9 & 8.3 & 6.8 & -0.1 & -0.1 & -0.1 & -0.2 \\
\hline SSI Benefits & 0.0 & 0.0 & 0.0 & 0.0 & 0.0 & 0.0 & 0.0 & 0.0 \\
\hline Imputed Rental Income & 3.4 & 3.5 & 3.1 & 3.3 & 0.0 & 0.0 & 0.0 & 0.0 \\
\hline Social Security Benefits & 15.7 & 16.3 & 15.8 & 15.5 & 0.0 & 0.0 & 0.0 & 0.0 \\
\hline DB Pension Benefits & 18.8 & 15.6 & 13.4 & 11.9 & -6.4 & -7.6 & -8.1 & -8.5 \\
\hline Retirement Accounts & 8.4 & 10.6 & 11.9 & 11.7 & 0.3 & 0.5 & 0.4 & 0.3 \\
\hline Total Income & 64.9 & 61.6 & 58.9 & 55.8 & -6.2 & -7.2 & -7.8 & -8.6 \\
\hline
\end{tabular}

Note: Projections exclude individuals with family wealth in the top 5 percent of the distribution. Losers are defined as having at least a $\$ 10$ decrease in income between the baseline and UK scenario.

Source: Authors' computations of MINT5 (see text for details). 


\section{RECENT WORKING PAPERS FROM THE}

\section{CENTER FOR RETIREMENT RESEARCH AT BOSTON COLLEGE}

\section{Retirement and Social Security: A Time Series Approach}

Brendan Cushing-Daniels and C. Eugene Steuerle, January 2009

Economic Restructuring and Retirement in Urban China

John Giles, January 2009

Sources of Support for Pension Reform: A Cross-National Perspective Michelle Dion and Andrew Roberts, January 2009

The Long-Term Effect of the Divorce Revolution: Health, Wealth, and Labor Supply

Kristin Mammen, December 2008

The Response of Household Saving to the Large Shock of German Reunification Nicola Fuchs-Schündeln, November 2008

A Parsimonious Choquet Model of Subjective Life Expectancy

Alexander Ludwig and Alexander Zimper, November 2008

Risky Pensions and Household Saving Over the Life Cycle

David A. Love and Paul A. Smith, November 2008

Identifying Local Differences in Retirement Patterns

Leora Friedberg, Michael Owyang, and Anthony Webb, November 2008

What Effect Do Time Constraints Have on the Age of Retirement? Leora Friedberg, Wei Sun, Anthony Webb, November 2008

Dual-Eligible Medicaid Spending: Are We on the Flat of the Curve?

Melissa A. Boyle, Joanna N. Lahey, and Margaret E. Czervionke, November 2008

Public Long-Term Care Insurance and the Housing and Living Arrangements of the Elderly: Evidence from Medicare Home Health Benefits

Gary V. Engelhardt and Nadia Greenhalgh-Stanley, November 2008

The Impact of Changing Earnings Volatility on Retirement Wealth Austin Nichols and Melissa M. Favreault, November 2008 